\title{
Influence of ocean tides and ice shelves on ocean-ice interactions and dense shelf water formation in the D'Urville Sea, Antarctica
}

\author{
Pierre-Vincent Huot ${ }^{\mathrm{a}, *}$, Thierry Fichefet ${ }^{\mathrm{a}}$, Nicolas C. Jourdain ${ }^{\mathrm{b}}$, Pierre Mathiot ${ }^{\mathrm{c}, \mathrm{b}}$, \\ Clément Rousset ${ }^{\mathrm{d}}$, Christoph Kittel ${ }^{\mathrm{e}}$, Xavier Fettweis ${ }^{\mathrm{e}}$ \\ ${ }^{a}$ Earth and Life Institute, George Lemaitre Centre for Earth and Climate Research, UCLouvain, Louvain-la-Neuve, Belgium \\ ${ }^{\mathrm{b}}$ Université Grenoble Alpes, CNRS/IRD/G-INP, IGE, Grenoble, France \\ c UK MetOffice, Exeter, United Kingdom \\ d LOCEAN, IPSL, Paris, France \\ ${ }^{\mathrm{e}}$ Laboratory of Climatology, Department of Geography, University of Liège, Liège, Belgium
}

\section{A R T I C L E I N F O}

\section{Keywords:}

East Antarctica

Sea ice

Ocean

Ice shelves

Tides

Dense Shelf Water

\begin{abstract}
A B S T R A C T
The D'Urville Sea, East Antarctica, is a major source of Dense Shelf Water (DSW), a precursor of Antarctic Bottom Water (AABW). AABW is a key water mass involved in the worldwide ocean circulation and longterm climate variability. The properties of AABW in global climate models suffer from several biases, making climate projections uncertain. These models are potentially omitting or misrepresenting important mechanisms involved in the formation of DSW, such as tides and ocean-ice shelf interactions. Recent studies pointed out that tides and ice shelves significantly influence the coastal seas of Antarctica, where AABW originates from. Yet, the implications of these two processes in the formation and evolution of DSW are poorly understood, in particular in the D'Urville Sea. Using a series of NEMO-LIM numerical simulations, we assess the sensitivity of dense water formation in the D'Urville Sea to the representation of tides and ocean-ice shelf interactions during the years 2010-2015. We show that the ice shelves off Adélie Land are highly sensitive to tidal forcing, with a significant basal melt increase in the presence of tides. Ice shelf basal melt freshens and cools the ocean over significant portions of the coastal seas at the depth of the ice shelf draft. An opposite warming and increase in salinity are found in the upper layers. The influence of ice shelf basal melt on the ocean is largely increased in the presence of tides. However, the production of sea ice is found to be mostly unaffected by these two processes. Water mass transport out of polynyas and ice shelf cavities are then investigated, together with their sensitivity to tides and ocean-ice shelf interactions. Ice shelf basal melt impacts the volume of dense waters in two ways: (1) Dense Shelf Water and Modified Shelf Water are consumed to form water masses of intermediate density inside the ice shelf cavities, and (2) the freshening of the ocean subsurface makes its transformation into dense water by sea ice formation more difficult. These results suggest that ice shelf basal melt variability can explain part of the observed changes of dense water properties, and may also affect the production of dense water in a future climate.
\end{abstract}

\section{Introduction}

As polar regions face changes at an alarming rate, concerns about their linkages with global climate emerge. It is indubitable that the reduction of the sea ice cover will affect the Earth's climate through changes in radiative balance (Curry et al., 1995), or that the ongoing melt of continental ice sheets will enhance sea level rise (Alley et al., 2005). However, the future of polar regions is uncertain. Amongst unsolved questions, the evolution of Antarctic Bottom Water (AABW) in a changing climate remains particularly challenging. AABW is the densest water mass found globally. Made of cold and saline water, it occupies a large portion of the World Ocean's sea floor (Johnson,
2008). AABW forms and sinks at high latitudes of the Southern Ocean, after mixing of cold and saline Dense Shelf Water (DSW) and warmer Cirumpolar Deep Water (CDW). Due to its long renewal time, AABW is able to store heat and $\mathrm{CO}_{2}$ for several centuries (Pardo et al., 2014). As AABW occupies a large portion of the World Ocean, any warming of this water would be accompanied by a global sea level rise due to thermal expansion (Purkey and Johnson, 2013). AABW also takes part in the low-frequency climate variability through its implication in the ocean thermohaline circulation (Stocker et al., 1992; Jacobs, 2004). Observations suggest that AABW has been undergoing significant changes in the recent past. For instance, Purkey and Johnson (2013) showed

\footnotetext{
* Corresponding author.

E-mail address: pierre-vincent.huot@uclouvain.be (P.-V. Huot).
} 
that the deep Southern Ocean has been warming and freshening over the past decades, in particular in the East Antarctic basins (Aoki et al., 2005; Rintoul, 2007), while Aoki et al. (2020) revealed a reversal of the trend after 2010. As modifications of AABW are expected to have far reaching consequences, such changes illustrate the need for trustworthy projections of future polar climate.

Unfortunately, the current generation of global climate models (GCMs) presents several biases in the Southern Ocean. In particular, they struggle to represent the current AABW properties. Sallée et al. (2013) found that the water masses of the Southern Ocean are too light and too warm in GCMs used in the CMIP5 (Climate Model Intercomparison Project phase 5) exercise. Heuzé et al. (2013) concluded that only a few CMIP5 models are able to form DSW along the coast of Antarctica, where intense DSW formation has been observed (Ohshima et al., 2013; Williams et al., 2008). Heuzé (2020) showed that numerous models from the CMIP6 exercise, while providing better results than their predecessors, produced most of the AABW through open-ocean convection. This questions the ability of GCMs to simulate the future of AABW and of the Earth's climate.

DSW (a precursor to AABW) forms when large amounts of salt are rejected during seawater freezing. The increase in surface water density destabilizes the water column and potentially leads to convection. High sea ice production required for DSW formation is mostly found in coastal seas of Antarctica (Tamura et al., 2008), where katabatic winds are frequent (Mathiot et al., 2010). The fine scale of polynyas and coastal katabatic winds makes their representation delicate in GCMs, which might be a cause for the lack of DSW formation. Besides, the importance of some processes occurring below the ocean surface may have been overlooked. The stratification of the ocean, and in particular the freshwater content in the water column are expected to interfere with the formation of DSW. For instance, De Lavergne et al. (2014) demonstrated that a surface freshening of the Southern Ocean could imply a cessation of deep convection in the Weddell Sea. Concerning the D'Urville Sea, Lacarra et al. (2014) proposed that ocean convection could also be reduced by the presence of a marked pycnocline following winters of intense DSW formation in areas of limited lateral exchange of bottom water properties. Finally, the properties of the dense water being produced would also depend on the state of the water masses being entrained during the winter convection. For instance, Circumpolar Deep Water (CDW) is believed to be involved in DSW formation (Mantyla and Reid, 1983). However, the understanding of the processes governing the presence of $\mathrm{CDW}$, the stratification and the properties of water masses of coastal seas of Antarctica is still incomplete.

Tides and ice shelf cavities have been ignored in studies based on GCMs. Models of the CMIP6 exercise do not explicitly represent tides and rely on parameterizations of tidal mixing. In several models, ocean-ice shelf interactions are either omitted, such as in GFDLCM4 (Held et al., 2019) or simply parameterized: freshwater flux from the ice sheet is for instance applied at the surface of the ocean in MPIESM (Jungclaus et al., 2013; Mauritsen et al., 2019). More sophisticated representations exist in HadGEM3 or IPSL models (Storkey et al., 2018; Boucher et al., 2020), where the freshwater flux is applied in subsurface to mimic the impact of ocean-ice shelf interactions. Few models, such as the AWI-CM (Wang et al., 2014; Semmler et al., 2019), represent ice shelf cavities. While this illustrates the effort put into accounting for this process in GCMs over the recent years, models with realistic representation of ocean-ice shelf interactions remain uncommon. However, a growing body of evidence suggests that these two processes have a substantial impact on the coastal seas of Antarctica. Tides can notably modulate the export of DSW out of the continental shelf over the spring/neap tidal cycle in the Ross Sea (Padman et al., 2009). They favor the inflow of warm CDW onto the continental shelf, alongside with the eddies (Stewart et al., 2018). They also influence DSW volume through an enhanced mixing between DSW and CDW (Wang et al., 2013). Simultaneously, tides can affect sea ice production through the periodic opening and closing of leads (Luneva et al., 2015) or sea ice motion (Koentopp et al., 2005). Tides are also a strong contributor to ice shelf basal melt (Makinson et al., 2011; Mueller et al., 2012; Arzeno et al., 2014; Padman et al., 2018; Jourdain et al., 2019; Hausmann et al., 2020). Besides, several studies emphasized the significant impact of ice shelves on ocean and sea ice. Numerical studies suggested that increases in ice shelf meltwater could favor (Bintanja et al., 2015), have no significant effect (Pauling et al., 2016), or even reduce the sea ice cover in some regions (Jourdain et al., 2017; Mathiot et al., 2017; Merino et al., 2018). Furthermore, enhanced ice shelf melting induces a subsurface warming all around Antarctica, with effects on AABW formation and the global climate system (Menviel et al., 2010; Fogwill et al., 2015; Bronselaer et al., 2018; Golledge et al., 2019; Schloesser et al., 2019). Moreover, Silvano et al. (2018) suggested that freshwater from ice shelf melting might suppress DSW formation in the Amundsen polynya (west Antarctica) and along the Sabrina coast (east Antarctica), but not in other regions such as the Cape Darnley polynya. The understanding of the mechanisms connecting tides and ice shelves to DSW formation is vague, in particular in other regions of the Southern Ocean.

The D'Urville Sea, located off Adélie Land in East Antarctica, is one of the major sources of DSW and AABW (Rintoul, 1998). This production is supported by the intense and persistent katabatic winds typical of the region (Wendler et al., 1997; Williams et al., 2008), favoring high rates of sea ice production (as shown by Mathiot et al., 2012). It has been the focus of several studies following the calving of the Mertz ice tongue in 2010, which led to a decrease in polynya activity and DSW production (Kusahara et al., 2011; Lacarra et al., 2014; Cougnon et al., 2017; Snow et al., 2018). Despite these studies, several questions remain concerning the processes involved in DSW formation in the D'Urville Sea. The influence of ice shelf basal melt on ocean circulation, sea ice and DSW production is not well understood yet, and no study has focused on the influence of tides on the cross-shelf exchange or ice shelf basal melt in this region.

The present study assesses the role of tides and ocean-ice shelf interactions in DSW formation in the d'Urville Sea. We investigate the influence of tides on ice shelf basal melt, the role of tides and ocean-ice shelf interactions on coastal sea water mass properties and circulation, and how these changes impact dense water. To do so, we run highresolution ocean-sea ice simulations of the D'Urville Sea incorporating both tides and ocean-ice shelf interactions. The model used is NEMOLIM 3.6 and it is forced by the ERA5 atmospheric reanalysis. The period of interest is 2010-2015. A series of sensitivity experiments is performed in which we turn off the representation of tides, ocean-ice shelf interactions or both processes together. We analyze the sensitivity of the ice shelf to tides, and how both processes affect the ocean mean state and the dense water production off Adélie Land. The paper is organized as follows. The model configuration and forcing as well as the experimental design are presented in Section 2. Our reference simulation is evaluated in Section 3. Sensitivity experiments to tides and ice shelves are analyzed in Section 4. A general discussion and conclusions are presented in Sections 5 and 6, respectively.

\section{The model, boundary conditions and experimental design}

We developed a regional configuration of the NEMO platform (Nucleus for European Modelling of the Ocean, Madec, 2016) in its version 3.6 together with the sea ice model LIM3.6 (Louvain-la-Neuve sea Ice Model). The ocean component is based on primitive equations, assuming hydrostatic balance and using the Boussinesq approximation. Parameterizations include a Turbulent Kinetic Energy scheme (Bougeault and Lacarrere, 1989; Gaspar et al., 1990) for vertical mixing, convection is represented by enhancing vertical mixing, the surface pressure gradient is treated with a time-splitting approach together with a nonlinear free surface. The grid is refined from the ORCA1 tripolar grid to obtain a locally isotropic resolution corresponding to $1 / 24^{\circ}$ longitude, 
i.e. from 1.7 to $2.3 \mathrm{~km}$ over the domain $\left(130^{\circ} \mathrm{E}-150^{\circ} \mathrm{E}\right.$ and $60^{\circ} \mathrm{S}$ $70^{\circ} \mathrm{S}$, see Fig. 1). This is not enough to fully resolve the eddies on the coastal seas where the 1 st baroclinic radius ranges from 1 to 6 $\mathrm{km}$ (Hallberg, 2013). The vertical discretization consists of 75 levels of increasing thickness from top to bottom (1 $\mathrm{m}$ at the ocean surface, $200 \mathrm{~m}$ at depths larger than $3500 \mathrm{~m}$ ), together with partial step of the bottom cells (and top cells under ice shelves). A no-slip lateral boundary condition is applied at the coast. The ocean time step is $150 \mathrm{~s}$. We use a polynomial approximation of the reference Thermodynamic Equation Of Seawater (TEOS-10) [IOC, SCOR, APSO, 2010] optimized for a Boussinesq fluid (Roquet et al. 2015). The sea ice component, LIM3.6, is a dynamic-thermodynamic model described in Vancoppenolle et al. (2009) and Rousset et al. (2015). The configuration of LIM in our model derives from the one of Rousset et al. (2015). A subgrid scale distribution of sea ice thickness is used with 5 categories. The time step for the sea ice model is set to $900 \mathrm{~s}$, with 600 subcycles to solve sea ice rheology. Sea ice-ocean and sea ice-atmosphere drag coefficients are $5.0 \times 10^{-3}$ and $1.4 \times 10^{-3}$, respectively.

Surface boundary fluxes are computed every $900 \mathrm{~s}$ using the CORE bulk formulas (Large and Yeager, 2004). No salinity restoring is applied. At the domain boundaries, a flow relaxation scheme (Engedahl, 1995) is applied to the three-dimensional ocean variables and twodimensional sea ice variables. A Flather scheme (Flather, 1994) is used for barotropic velocities and sea surface elevation. Ice shelf cavities with explicit ocean-ice shelf interactions are represented by the ice shelf module introduced in NEMO by Mathiot et al. (2017), i.e. using the three-equations formulation from Jenkins (1991). Transfer coefficients are velocity dependent: $\gamma_{T, S}=\Gamma_{T, S} \times u_{*}$. The friction velocity is given by $u_{*}=C d \times \sqrt{u_{T M L}^{2}}$ and constant values of $\Gamma_{T, S}$ taken from Jourdain et al. (2017) are used $\left(\Gamma_{T}=2.21 \times 10^{-2}\right.$ and $\Gamma_{S}=$ $6.4 \times 10^{-5}$ for temperature and salinity, respectively), $C_{d}$ is the top drag coefficient, set to $2 \times 10^{-3}$, and $u_{T M L}$ is the ocean velocity in the top boundary layer (Losch, 2008). The thickness of the top boundary layer equals the thickness of the top wet cell.

Bathymetry is adapted from the GEBCO dataset (Weatherall et al., 2015), which includes the high-resolution measurements from Beaman et al. (2011). To ensure consistency with boundary conditions, the bathymetry at the boundaries is set to the bathymetry of the reanalysis used as lateral forcing. The B9B iceberg is mapped from LANDSAT8 images and added as an ice shelf. A second iceberg is added on the Dibble Bank, in the western part of the domain. Both iceberg locations appear to be almost unchanged over the period 2011-2015. B9B iceberg draft is set to $300 \mathrm{~m}$ following Mayet et al. (2013) and is treated as an ice shelf. We also set the Dibble iceberg draft to $300 \mathrm{~m}$. Ice draft and bathymetry under ice shelves are adapted from Bedmap2 dataset (Fretwell et al., 2013). Bathymetry and ice draft are illustrated in Fig. 1.

Tidal velocities and elevation of 18 tidal constituents from the Finite Element Solution 2012 (FES2012, Carrère et al. (2012)) are applied at the domain boundaries as in Maraldi et al. (2013) and Jourdain et al. (2019). To assess the representation of tides in our model configuration, we first run a pseudo-barotropic experiment as in Maraldi et al. (2013) and Jourdain et al. (2019). This simulation is referred to as BARO hereafter. The results are compared to FES2012 in Fig. 2. The simulated tidal velocity is in good agreement with the external solution FES2012 for the semidiurnal component (here M2), with a RMSE of $0.49 \mathrm{~cm} / \mathrm{s}$ and a mean bias of $+0.12 \mathrm{~cm} / \mathrm{s}$ over the continental shelf. The amplitude of the diurnal tidal velocities (here O1) is underestimated in BARO, especially at the shelf break, with a mean bias of $-2.2 \mathrm{~cm} / \mathrm{s}$ over the continental shelf.

The surface boundary conditions are derived from the 3-hourly ERA5 atmospheric reanalysis (Hersbach et al., 2020). The iceberg melt climatology of Merino et al. (2016) is used as an additional freshwater flux. Boundary conditions for ocean and sea ice at daily frequency are derived from the $1 / 12^{\circ}$ PSY4V3R1 ocean and sea ice analysis (https://www.mercator-ocean.fr/). It assimilates sea surface temperatures from OSTIA (Donlon et al., 2012), sea ice concentration from OSISAF (EUMETSAT, 2015), and temperature and salinity from the CORA4.1 dataset (Cabanes et al., 2013) and WOA13 (Zweng et al., 2013; Locarnini et al., 2013) below $2000 \mathrm{~m}$ depth. In order to reduce biases present on the coastal seas in the analysis used as lateral boundaries, we apply a correction towards the WOA18 climatology (Locarnini et al., 2018; Zweng et al., 2018). The temperature and salinity of the WOA18 climatology are imposed and daily anomalies from the PSY4V3R1 analysis with respect to their climatological values are added. The correction is only applied on the continental shelf (defined as the portions of the domain boundary where the bathymetry is shallower than $1000 \mathrm{~m}$ ) because PSY4V3R1 shows better agreement with the observations in the open ocean and in order to reduce model instabilities. To minimize the mismatch between the surface water properties and sea ice conditions, the first ocean level is left unchanged, the correction is then linearly applied between $\mathrm{z}=1 \mathrm{~m}$ and $\mathrm{z}=10$ $\mathrm{m}$. To avoid a sharp lateral contrast between the shelf seas and the offshore ocean, the strength of the correction is linearly decreased on the 10 points following the shelf break. A constant sea ice salinity of $10 \mathrm{~g} / \mathrm{kg}$ as well as a sea ice temperature of $-3.15^{\circ} \mathrm{C}$ are applied at the boundaries. A predefined sea ice thickness distribution is used for distributing the cell average thickness from PSY4V3R1 into the 5 categories of our simulations.

Large portions of the Adélie shelf seas are covered by patches of landfast sea ice (sea ice fastened to the coast, to the ice shelf tongues or to grounded icebergs, see Fraser et al., 2012), often combined with the opening of polynyas on their lee side (Nihashi and Ohshima, 2015). Kusahara et al. (2010) successfully simulated the polynyas off Adélie Land by imposing barriers to sea ice advection as a way of mimicking the presence of icebergs. Fraser et al. (2012) suggested that landfast ice can form in a field of isolated grounded icebergs. This hypothesis is supported by the results of Olason (2016), who showed that the arching of sea ice anchored to several islands could lead to the formation of landfast sea ice, provided that the sea ice can offer tensile strength. This process was included in a viscous-plastic sea ice model by Lemieux et al. (2016) for the Arctic Ocean. The sea ice rheology from our model was adapted following Lemieux et al. (2016) to increase the sea ice tensile strength. The spatial distribution of small grounded icebergs off Adélie Land was obtained from the analysis of LANDSAT images taken between 2010 and 2015 (see Fig. 1). These grounded icebergs are treated as land in the sea ice model and they mask air-sea fluxes. They do not produce freshwater as the contribution of icebergs to the freshwater budget is already accounted for in the runoff (as it includes the iceberg melt climatology of Merino et al., 2018) or is computed interactively in the case of the B9B iceberg (treated as an ice shelf). The ocean currents are free to cross grounded icebergs (as in Kusahara et al., 2017).

Our experimental design consists of a reference simulation and a set of sensitivity experiments. All simulations start from the WOA18 climatology in January 2007 and are run from 2007 to 2015. Years 2007-2009 are discarded from the analysis. The reference simulation (denoted REF) includes both tides and ocean-ice shelf interactions (open ice shelf cavities and interactive basal melt). In the noT simulation, the tidal forcing at the domain boundary is turned off. In noI, the under ice shelf cavities are masked and there is no freshwater or heat flux at the ocean-ice shelf interface. This is done to completely remove the effect of ocean-ice shelf interactions. Simulation noA has both tides and ocean-ice shelf interactions turned off, with the same methodology as noI and noT. Table 1 summarizes the simulations.

\section{Model evaluation}

\subsection{Sea ice}

In order to evaluate our simulation, two sea ice concentration datasets are used: the OSI450 (Lavergne et al., 2019) and ASI-SSMI 


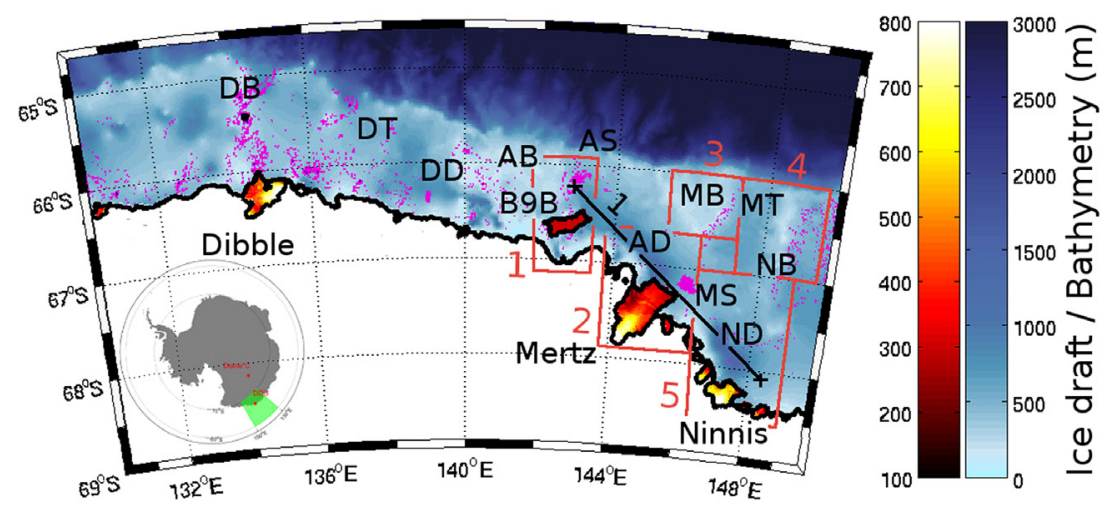

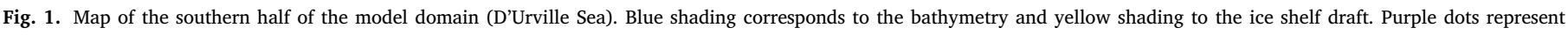

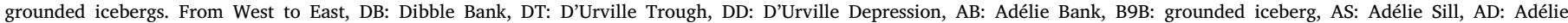

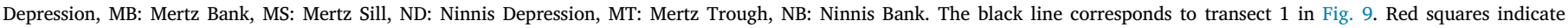
boxes for water mass transport computation (Fig. 11). 1: B9B polynya, 2: Mertz Glacier Polynya, 3: Mertz Bank Polynya, 4: Ninnis Bank Polynya, 5: Ninnis Glacier Polynya.

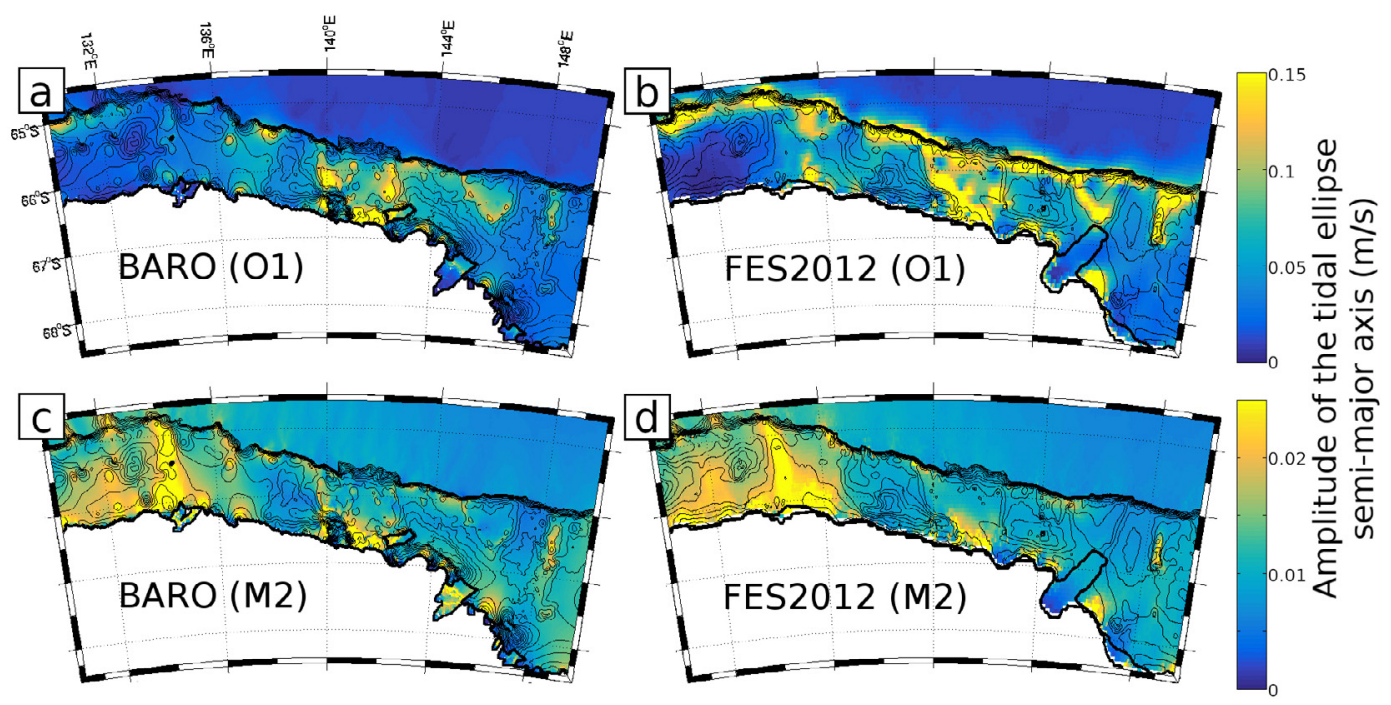

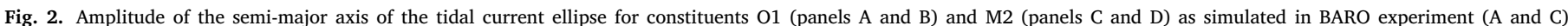

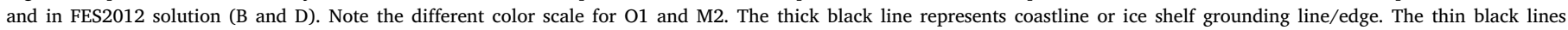

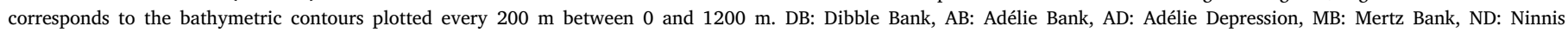
Depression, NB: Ninnis Bank.

Table 1

Names and descriptions of the simulations performed in the present study.

\begin{tabular}{lll}
\hline & Tides & Ice shelves \\
\hline REF & Yes & Yes (cavity and flux) \\
noT & No & Yes (cavity and flux) \\
noI & Yes & No (closed and no flux) \\
noA & No & No (closed and no flux) \\
BARO & Yes & Yes (cavity and no flux) \\
\hline
\end{tabular}

products (Spreen et al., 2008; Kaleschke et al., 2001). The two datasets have different resolutions: $12.5 \mathrm{~km}$ for ASI-SSMI and $25 \mathrm{~km}$ for OSI450. We compare the simulated sea ice concentrations in REF with these satellite products over 2010-2015 (Fig. 3). The simulated and observed sea ice extents in summer (January, February, March) are limited to the continental shelf (south of $65^{\circ} \mathrm{S}$ ). The model represents the spatial distribution of sea ice concentration reasonably well but has a tendency to underestimate the summer sea ice cover. It can be noted that a peninsula is present in the western part of the domain in ASISSMI, but not in the bathymetry and ice scape dataset used for the model. LANDSAT-8 images covering 2010-2015 (supplementary figure A.1) reveal that there is no such peninsula or ice tongue during our simulated period, but rather a large number of small grounded icebergs and associated landfast ice.

The simulated sea ice extent in winter (May, June, July, August, September) is in good agreement with ASI-SSMI. Sea ice concentrations higher than 0.8 are found south of $64^{\circ} \mathrm{S}$ in both the model and observations, and the average ice edge is located around $62^{\circ} \mathrm{S}$. On the continental shelf, our model tends to locally overestimate the sea ice concentration.

The temporal evolution of the total sea ice area as observed in OSI450 and ASI-SSMI and as simulated in REF is illustrated in panel E of Fig. 3. The interannual variability of the total sea ice area is well captured by our model, with a correlation of 0.97 (significant at $2 \sigma$ ) between REF and ASI-SSMI or OSI450. The absolute maximum of sea ice area is reached in both the model and observations in winter 2011, and the maximum high summer sea ice area observed in 2013 is also reproduced by the model. It can be noted that the interannual variability of sea ice area is large, with maximas ranging between $3.5 \times 10^{5} \mathrm{~km}^{2}$ (in 2015) and $5 \times 10^{5} \mathrm{~km}^{2}$ (in 2011).

Thanks to the inclusions of grounded icebergs and to the modification of the sea ice rheology to account for its tensile strength, the model produces large areas of landfast sea ice and several polynyas. Landfast ice covers large portions of the continental shelf (Fig. 4b). 

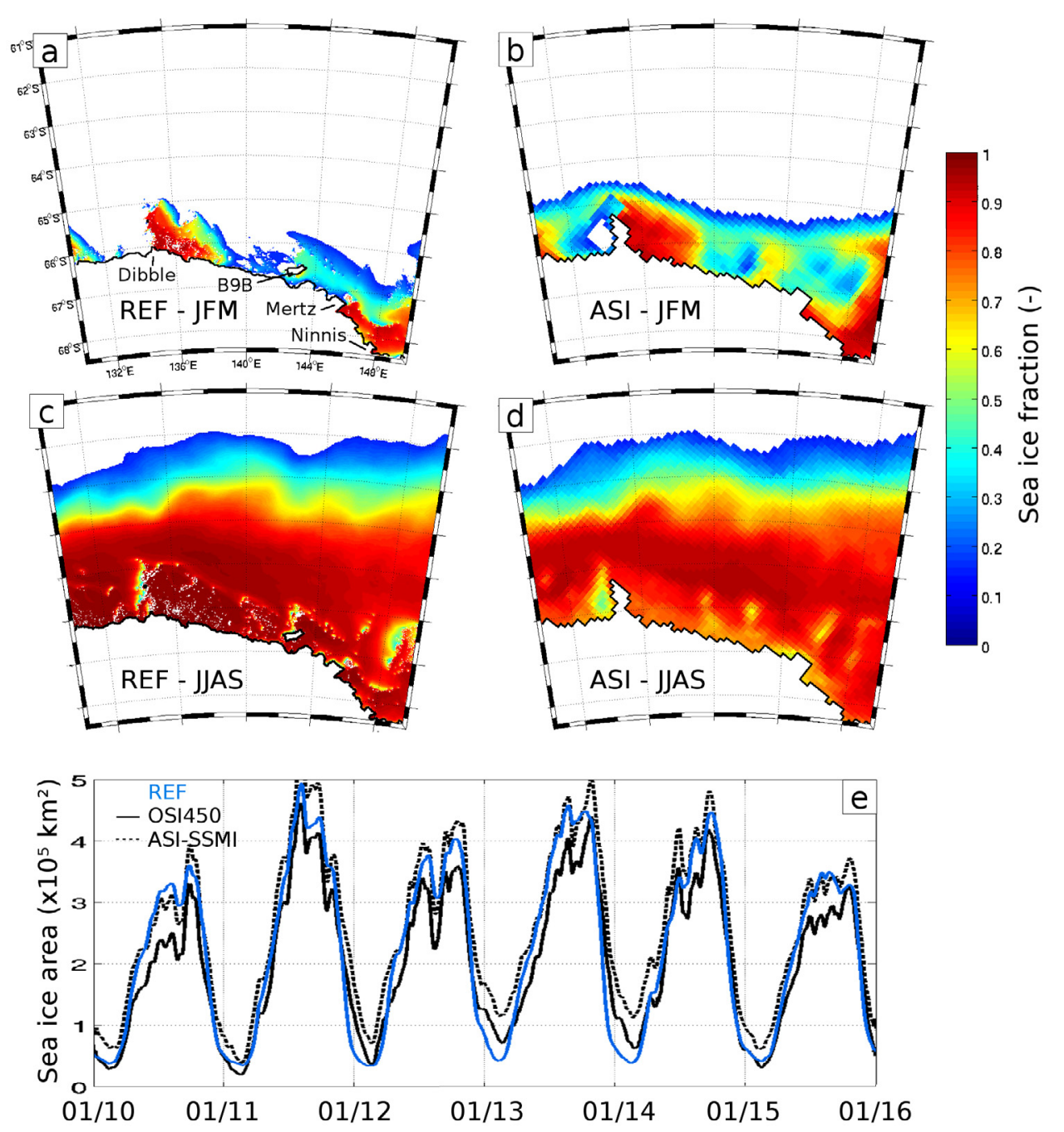

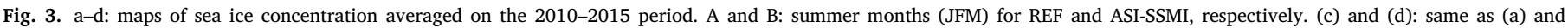

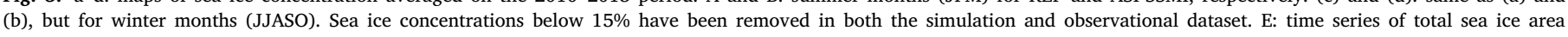
(where sea ice concentration $>15 \%$ ) as simulated by REF and observed in OSI 450 (continuous line) and ASI-SSMI (dashed line).

Patches of landfast sea ice form windward of grounded icebergs (on the Dibble, Adélie, Mertz and Ninnis banks) or ice shelf tongues (Mertz and Ninnis Glaciers). The spatial distribution of landfast sea ice simulated by the model is in good agreement with the one described by Fraser et al. (2012). The largest difference between the model and Fraser's dataset is located on the eastern side of the D'Urville Sea: this is due to the calving of the Mertz Ice Tongue and the relocation of the B9B which blocked sea ice further upwind before 2010. The occurrence of polynyas (Fig. 4a) closely matches the location of landfast ice patches. Six regions appear to be frequently free of sea ice during winter. They can be found on the lee side of the landfast ice patches. Only the Mertz Polynya is directly attached to the coast. Distinct processes might be at play for the formation of these polynyas, as suggested by Massom et al. (1998): the Mertz Polynya is driven by katabatic wind while the other polynyas are forced by the prevailing easterly winds. The estimated and simulated amount of sea ice produced in the polynyas off Adélie Land are indicated in Table 2. The simulation underestimates the volume of sea ice produced compared to Tamura et al. (2016), in particular due to lower sea ice production in the Mertz Bank and Ninnis Bank polynyas (MBP and NBP) and to the absence of the polynya at $140^{\circ} \mathrm{E}$. This might be due to a failure of the sea ice model to simulate certain polynyas, weak offshore winds, or to a potential overestimation of the sea ice production by Tamura et al. (2016), as they make the hypothesis that all the heat loss by the ocean is used for seawater freezing, and not to
Table 2

Yearly sea ice production $\left(\mathrm{km}^{3}\right)$ in the polynyas off Adélie Land (see Fig. 4 for polynya locations) and over the entire continental shelf, as simulated in REF and as estimated by Tamura et al. (2016). Averaged between 2011 and 2013.

\begin{tabular}{lll}
\hline Polynya & REF & Tamura et al. (2016) \\
\hline DBP & $72.10_{-}^{+7.94}$ & $67.34_{-}^{+4.48}$ \\
B9BP & $45.52_{-1.75}$ & $38.94_{-}^{+} 5.55$ \\
MGP & $36.01_{-}^{+} 1.99$ & $14.55_{-}^{+} 3.01$ \\
MBP & $24.29_{-}^{+} 3.01$ & $36.69_{-}^{+} 0.53$ \\
NGP & $43.12_{-}^{+3.97}$ & $31.50_{-}^{+} 12.15$ \\
NBP & $21.96_{-}^{+} 1.05$ & $36.78_{-}^{+} 4.06$ \\
Shelf & $337.73_{-}^{+} 19.32$ & $409.28_{-}^{+4} 41.69$ \\
\hline
\end{tabular}

cool down the ocean. On the contrary, the model overestimates sea ice production in the Mertz and Ninnis Glacier polynyas.

\subsection{Water masses}

The simulated ocean properties on the continental shelf off Adélie Land are compared against CTD measurements from the World Ocean Database 2018 in Fig. 5a, b. Only the measurements obtained after 2010 are taken into account as the simulation is performed with the post-calving ice shelf geometry (after the Mertz calving in 2010 and B9B relocation in 2011). The simulated temperatures are in good 

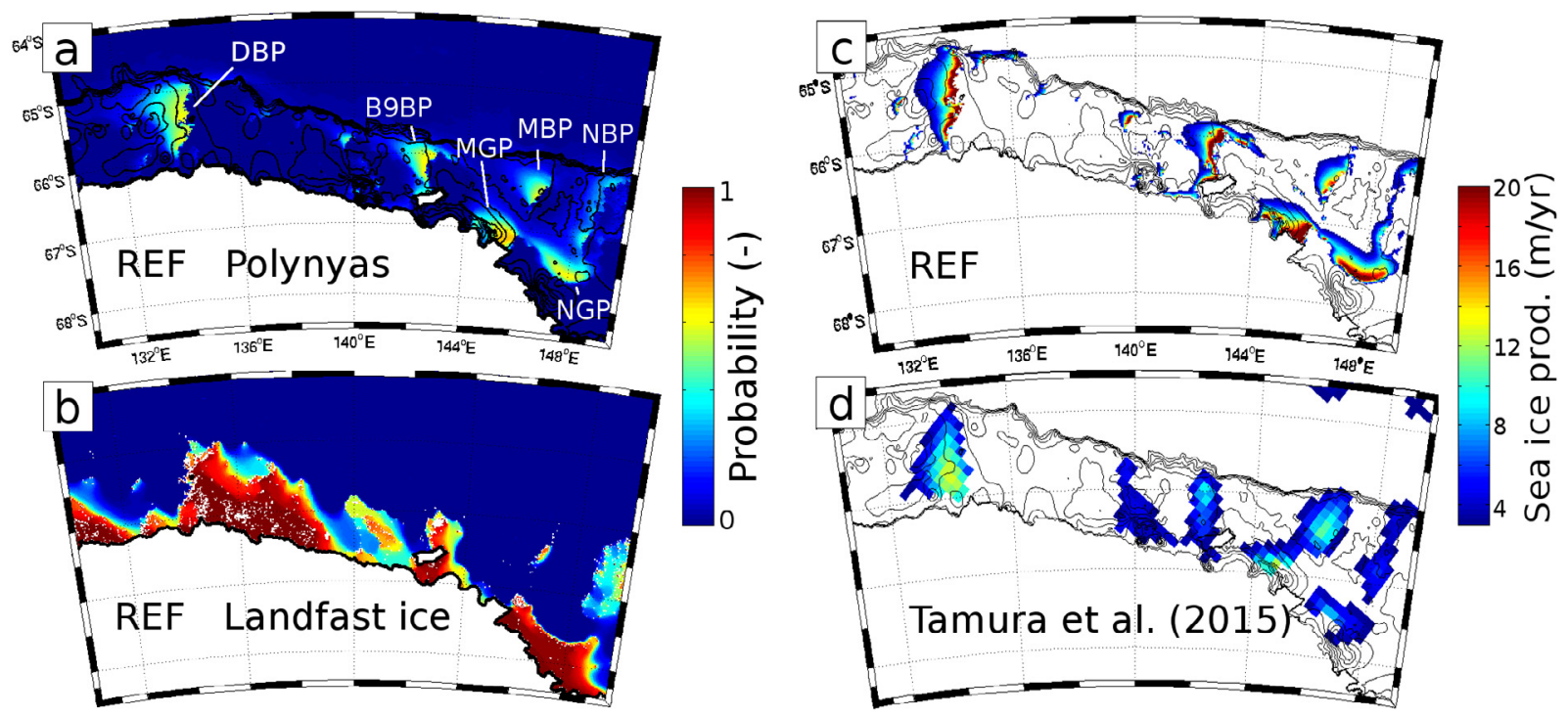

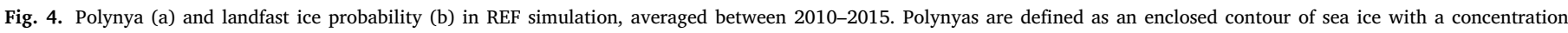

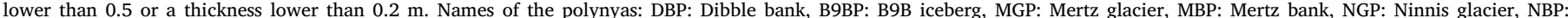

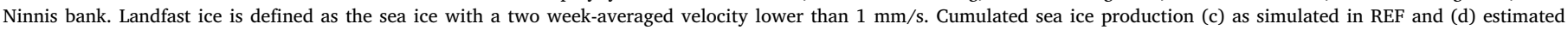

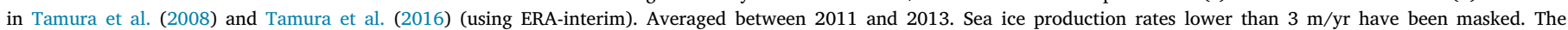
simulated sea ice production rate is the sum of the freezing of open water and the growth of sea ice thinner than $0.2 \mathrm{~m}$, as in Tamura et al. (2016).
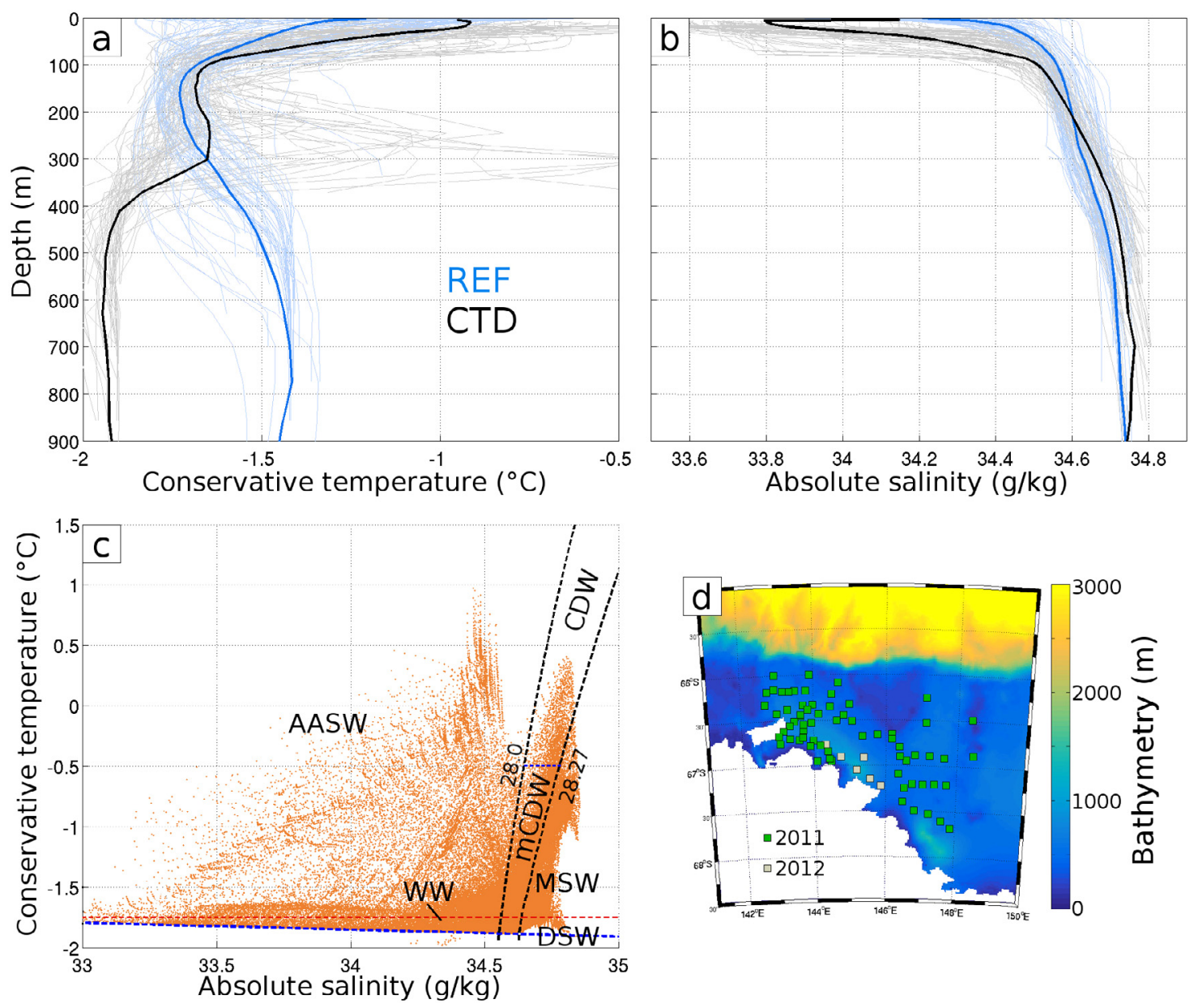

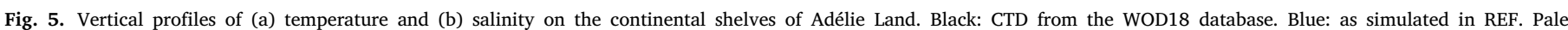

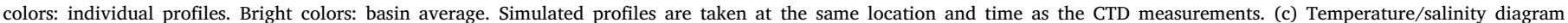

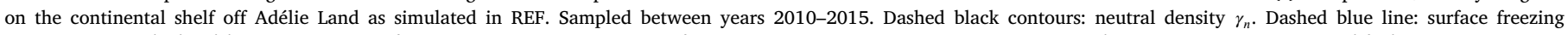

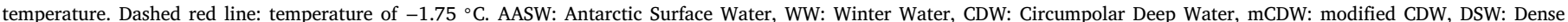
Shelf Water, MSW: Modified Shelf Water. (d) locations of CTDs used in panels (a) and (b). 
agreement with the observations down to $300 \mathrm{~m}$, then the simulation exhibits a warm bias of $0.5{ }^{\circ} \mathrm{C}$. The simulated salinity is higher than the observed one in the top $200 \mathrm{~m}$, and slightly lower deeper in the water column. The different water masses simulated in the d'Urville Sea are shown on the diagram of Fig. 5c. Water masses can be divided in several poles with distinct properties. Antarctic surface water (AASW) corresponds to water with temperature ranging from -1.7 to $1{ }^{\circ} \mathrm{C}$ and relatively low salinity. Winter Water (WW) is a relatively saline and cold (below $-1.7^{\circ} \mathrm{C}$ ) water mass, formed during the destratification in winter. Following Lacarra et al. (2014) and Whitworth et al. (1998), we use the neutral density $\gamma_{n}$ to discriminate the dense water masses. The pole of Circumpolar Deep Water (CDW) is defined as the water mass with $\gamma_{n}$ between 28.0 and $28.27 \mathrm{~kg} / \mathrm{m}^{3}$, together with a relatively high temperature. We divide this pole in two water masses identified by their temperature: relatively pure $\mathrm{CDW}$ has a temperature above $-0.5{ }^{\circ} \mathrm{C}$, while modified CDW (mCDW) is cooler. The densest WW forms the Dense Shelf Waters (DSW). We define Dense Shelf Water (DSW) as the water mass with $\gamma_{n}>28.27 \mathrm{~kg} / \mathrm{m}^{3}$ and a temperature below $-1.75{ }^{\circ} \mathrm{C}$. Modified Shelf Water (MSW) is a water mass with $\gamma_{n}>28.27 \mathrm{~kg} / \mathrm{m}^{3}$ and a temperature above $-1.75{ }^{\circ} \mathrm{C}$. We also define the Shelf Waters (SW) as the water mass with $\gamma_{n}>28.27 \mathrm{~kg} / \mathrm{m}^{3}$ with no distinction on the temperature.

The volume of SW present in summer (January to March) in the WOA18 climatology (decade 2005-2017) is estimated to be $5.58 \times 10^{12}$ $\mathrm{m}^{3}$, with $3.95 \times 10^{12} \mathrm{~m}^{3}$ of DSW. In the REF simulation, there are $3.88 \times 10^{12} \mathrm{~m}^{3}$ of SW, which are made up of more than $90 \%$ of MSW (only $0.2 \times 10^{12} \mathrm{~m}^{3}$ of DSW). The DSW produced in winter in REF (see Section 4.3.1) is quickly exported or converted in MSW after mixing with CDW. In addition, REF simulates frequent advection of MSW from the Mertz Trough into the Adélie Depression (supplementary figure A.4). This MSW can fill the depressions as it is as dense as the simulated DSW. It is worth noting that the WOA18 climatology used here is built upon data from 2005 to 2017, thus incorporating measurements anterior to the 2010 calving and associated regime shift. Moreover, the simulated ocean had several years to adjust to the post-calving coastline and ice scape thanks to the spin-up, while the actual ocean might still be adjusting to this event (CTD casts performed after 2015 suggest the replacement of some DSW by MSW in the Adélie Depression, see supplementary Figure A.3). The potential limitations emerging from this bias are presented and commented in Section 5 .

\subsection{Ice shelves}

The averaged basal melt rate of the major ice shelves or icebergs off Adélie Land obtained in the REF simulation between years 2010 and 2015 are shown in supplementary Figure A.5 and compared to estimates of Rignot et al. (2013), Depoorter et al. (2013) and Adusumilli et al. (2020) (hereafter R13, D13 and A20 respectively) in Table 3. The simulated basal melt rates are lower than the estimates from R13 and D13 for the Dibble ice shelf and larger for the Mertz and Ninnis ice shelves. The simulated Mertz basal melt is however lower than the estimates of A20. The basal melt estimates of R13 and D13 were obtained using mostly data from the years 2000-2010. This limits direct comparison due to potential decadal variability. Moreover, the Mertz and Ninnis ice shelves have undergone drastic changes over the past decades. For instance, the Ninnis ice tongue calved in 2000 and the Mertz one in early 2010. These events had important repercussions for sea ice production, ocean circulation and glacier dynamics, with possible consequences for the basal melt rates (Cougnon et al., 2017; Kusahara et al., 2017). Previous studies also suggested different basal melt rate values for these ice shelves: Berthier et al. (2003) and Rignot (2002) estimated the basal melt rate of the Mertz glacier to be $11 \mathrm{~m} / \mathrm{yr}$ and $18 \mathrm{~m} / \mathrm{yr}$, respectively.
Table 3

Basal melt rate (in $\mathrm{m} / \mathrm{yr}$ ) and its interannual standard deviation for major ice shelves as simulated in REF and as estimated from observations by Rignot et al. (2013), Depoorter et al. (2013) and Adusumilli et al. (2020) (R13, D13 and A20, respectively).

\begin{tabular}{lllllll}
\hline & REF & & & & & \\
\cline { 2 - 4 } & Avg. & Std. & Min.-Max. & R13 & D13 & A20 \\
\hline Dibble & 3.08 & 0.94 & $1.82-4.04$ & $5.5_{-}^{+0} 0.9$ & $6.5_{-2}^{+2}$ & - \\
Mertz & 2.79 & 0.91 & $1.62-4.02$ & $1.4_{-}^{+} 0.6$ & $0.8_{-}^{+0.7}$ & $5.0_{-}^{+} 2.4$ \\
Ninnis & 3.35 & 1.09 & $2.10-4.52$ & $1.2_{-}^{+} 2$ & $0_{-}^{+1.5}$ & -
\end{tabular}

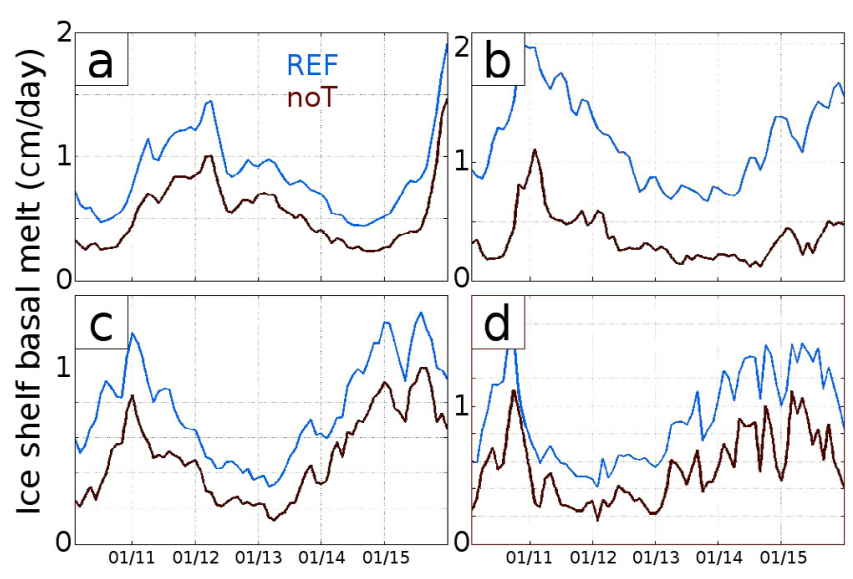

Fig. 6. Monthly basal melt rate of the three largest ice shelves of Adélie Land and iceberg B9B. a: Dibble, b: B9B, c: Mertz and d: Ninnis. Dark red curve: without tides (noT), blue curve: with tides (REF).

\section{Sensitivity of ice, ocean and DSW to tides and ice shelves}

\subsection{Ice shelf melting induced by tides}

In this section, we analyze the sensitivity to ocean-ice shelf interactions, which is in fact a sensitivity to the presence of an ice shelf cavity and to the associated heat and freshwater fluxes (see Section 2). Tides and ocean-ice shelf interactions are closely linked processes, and part of their effects can arise from interplay between each other. Therefore, we first evaluate the sensitivity of the basal melt of Adélie Land's ice shelves to tides.

Tides lead to an increase in ice shelf and iceberg basal melt rates (Fig. 6). The relative increase in basal melt is comparable between the three ice shelves ( $+62 \%$ for Dibble and Mertz and $+72 \%$ for Ninnis). It reaches a much higher value of $+250 \%$ for the B9B iceberg.

Tides can affect ice shelf basal melt through dynamical and thermodynamical effects (Jourdain et al., 2019). In the first case, tidal velocities enhance the turbulent heat flux at the ice-ocean interface. In the second case, tides induce changes in ocean temperature and salinity at the ice-ocean interface either through the mean tidal circulation or tidal mixing. In the simulations with ice shelves, the heat flux from the ocean to the ice shelf is computed as: $\rho_{w} c_{w} \gamma_{T}\left(T-T_{0}\right)$, with $\rho_{w}$ the density of seawater, $c_{w}$ the specific heat of seawater, $\gamma_{T}$ the transfer velocity, $T$ the temperature of seawater and $T_{0}$ the freezing point of seawater computed at the depth of the ice shelf and using the salinity $S_{b}$ at the ice-ocean interface (following Jenkins, 1991). Here, we define the tidal dynamical forcing as the difference in $\gamma_{T}$ and the tidal thermal forcing as the difference in the term $T-T_{0}$ between simulations REF and noT. The two contributions are illustrated in the maps of Fig. 7. Tides increase $\gamma_{T}$ over most of the ice shelves (Fig. $7 \mathrm{~b}$ and d). $\gamma_{T}$ is twice as large in REF than in noT for the Mertz, Ninnis and Dibble ice shelves. Even larger changes are observed beneath the B9B iceberg, where $\gamma_{T}$ is increased by a factor 5 . This strong sensitivity to tides arises from the large amplitude of tidal velocities found beneath B9B (Fig. 2 and also supplementary Figure A.2). The thermal effect of tides 
Thermal forcing

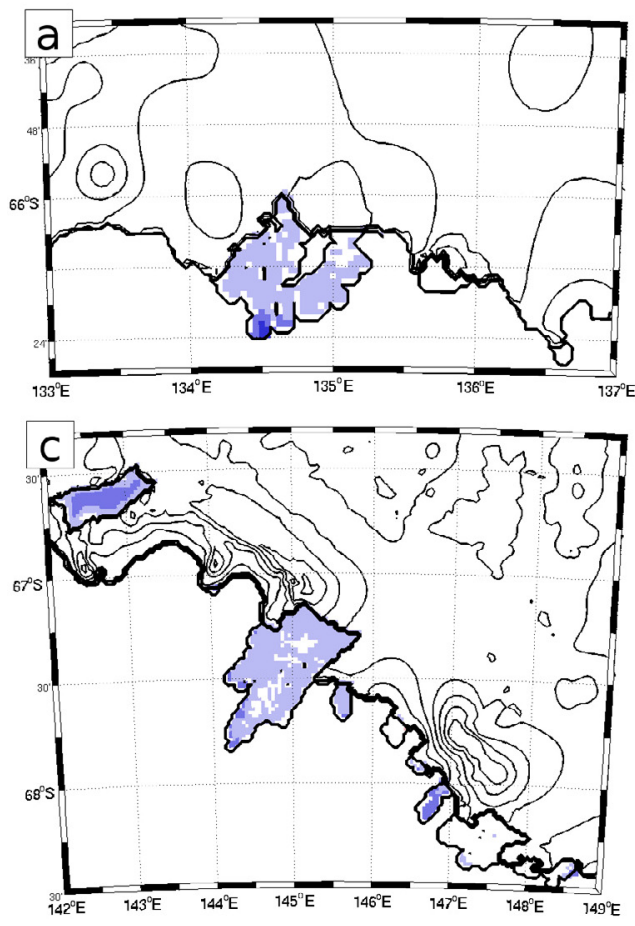

\section{Dynamical forcing}

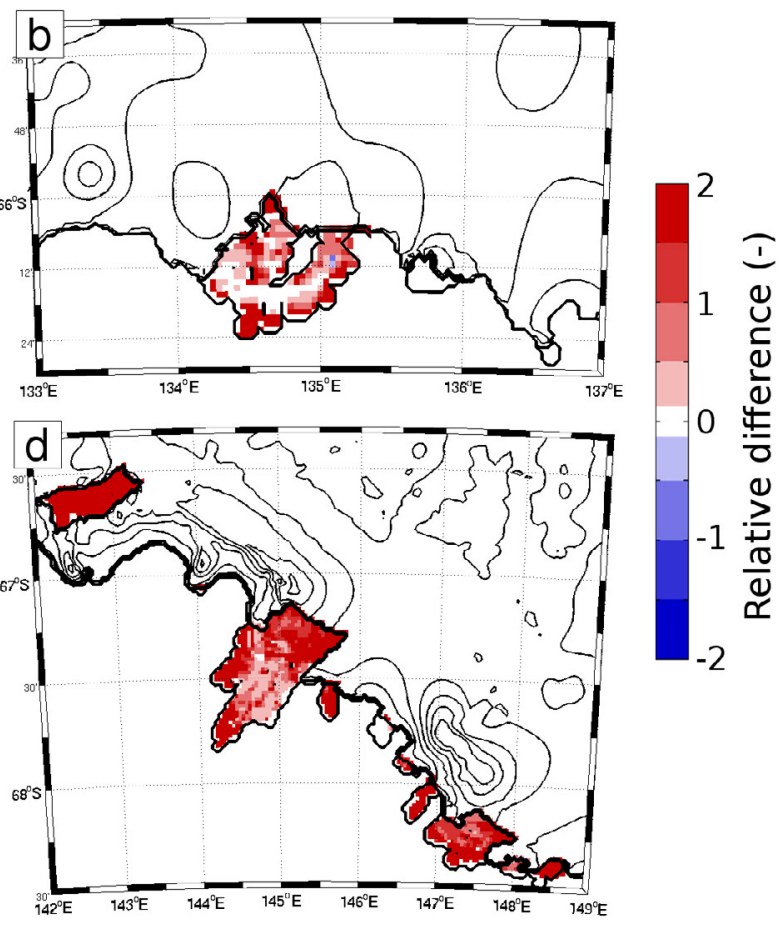

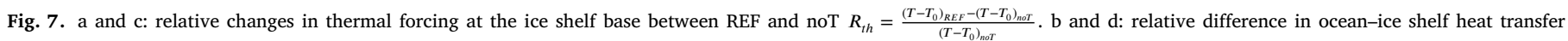
velocity between REF and noT $R_{d y n}=\frac{\left(\gamma_{T R E F}-\gamma_{T n T}\right)}{\gamma_{T_{n o T}}}$. Dibble: a and b: B9B, Mertz and Ninnis: c and d. Averaged between 2013 and 2015.

(Fig. 7a and c) partly compensates the dynamical forcing, likely because more dynamically induced melting tends to cool the top boundary layer beneath ice shelves (Jourdain et al., 2019). The ice shelves indeed undergo a decreased thermal forcing in the presence of tides, with variable magnitude : almost null for Ninnis, less than $50 \%$ decrease for Mertz and Dibble and slighlty above $50 \%$ for the B9B, which may be related to the strength of the dynamical tidal forcing beneath the B9B.

\subsection{Effect of tides and ocean-ice shelf interactions on the modeled ocean mean state}

The ocean mean state, the mean circulation and the mean sea ice production simulated in REF are shown on Fig. 8. Relatively warm and saline mCDW occupies the northernmost part of the continental shelf, on the east of the Mertz and Ninnis banks. Cooler and relatively fresher water masses are found along the coast, in the southwestern half of the Adélie Depression and west of the Adélie Bank. The mean ocean circulation on the continental shelf consists of a westward current crossing the Adélie Depression from the east to the northwest. This current forms east of the Mertz Sill, from the confluence of a cold and fresh coastal current from the south and the inflow of CDW from the north. This confluence leads to the sporadic inflow of mCDW into the Adélie Depression (intrusions of mCDW from the east were suggested by Snow et al., 2016 and Martin et al., 2017).

As tides substantially influence ocean-ice shelf interactions, it can be of interest to differentiate the individual effect of each process and the effect of the interactions between tides and ice shelf. To isolate the effect of ocean-ice shelf interactions, we compute the differences between the simulations noT and noA (respectively noI and noA for the effect of tides). The effect of the interactions between tides and ice shelf (namely the tide-induced basal melt increase, hereafter tides-ice shelf interactions) can be obtained by subtracting the combination of the effects of tides and ocean-ice shelf interactions considered separately, namely noI-noA and noT-noA, to the total effect REF-noA.
To understand how ice shelf basal melt and tides affect the water column, we investigate the differences in ocean temperature and salinity between the sensitivity experiments as a function of depth along Section 1 of Fig. 1. Results are displayed in Fig. 9. This section is roughly parallel to the coastline and follows the mean westward current (see Fig. 8). In simulation REF, the current first encounters the Ninnis ice shelf in the Ninnis depression, where the ocean undergoes a first cooling and freshening. At the Mertz Sill, the confluence with the current from the north-east carrying CDW induces a slight warming. A second cooling and freshening occur after passing by the Mertz ice shelf.

The influence of ocean-ice shelf interactions on the water column is illustrated on panels (b) and ( $g$ ) of Fig. 9. A subsurface cooling and freshening takes place in the lee of the ice shelves $\left(-0.1{ }^{\circ} \mathrm{C}\right.$ and $-0.02 \mathrm{~g} / \mathrm{kg}$ after Ninnis, $-0.2{ }^{\circ} \mathrm{C}$ and $-0.05 \mathrm{~g} / \mathrm{kg}$ after Mertz and B9B). This signal is located at the depth of the ice shelf base (around $500 \mathrm{~m}$ for Ninnis, $400 \mathrm{~m}$ for Mertz and $300 \mathrm{~m}$ for B9B). An opposite effect (warming and salinity increase) takes place in the top $200 \mathrm{~m}$ in the Adélie Depression. Tides (panels c and h of Fig. 9c, h) lead to a slight cooling below $200 \mathrm{~m}$ and a rise in salinity in the top 200 $\mathrm{m}$ of the Adélie Depression. The salinity and temperature anomalies described previously are also present with a stronger magnitude when both tides and ocean-ice shelf interactions are present (Fig. 9d, i). The interactions between tides and ice shelves (Fig. 9e, j) are computed following the methodology described in the previous paragraph. They further intensify the effect of the ice shelves on the ocean. The results presented here are also shown as maps in supplementary Figures A.7, A.8 and A.9.

\subsection{Water mass transport and production of dense water}

\subsubsection{Dense water production and interannual variability}

The temporal evolution of the salinity in the water column of each polynya simulated in REF is illustrated in Fig. 10. Fresh water occupies the top of the water column in summer. As the surface salinity rises in 

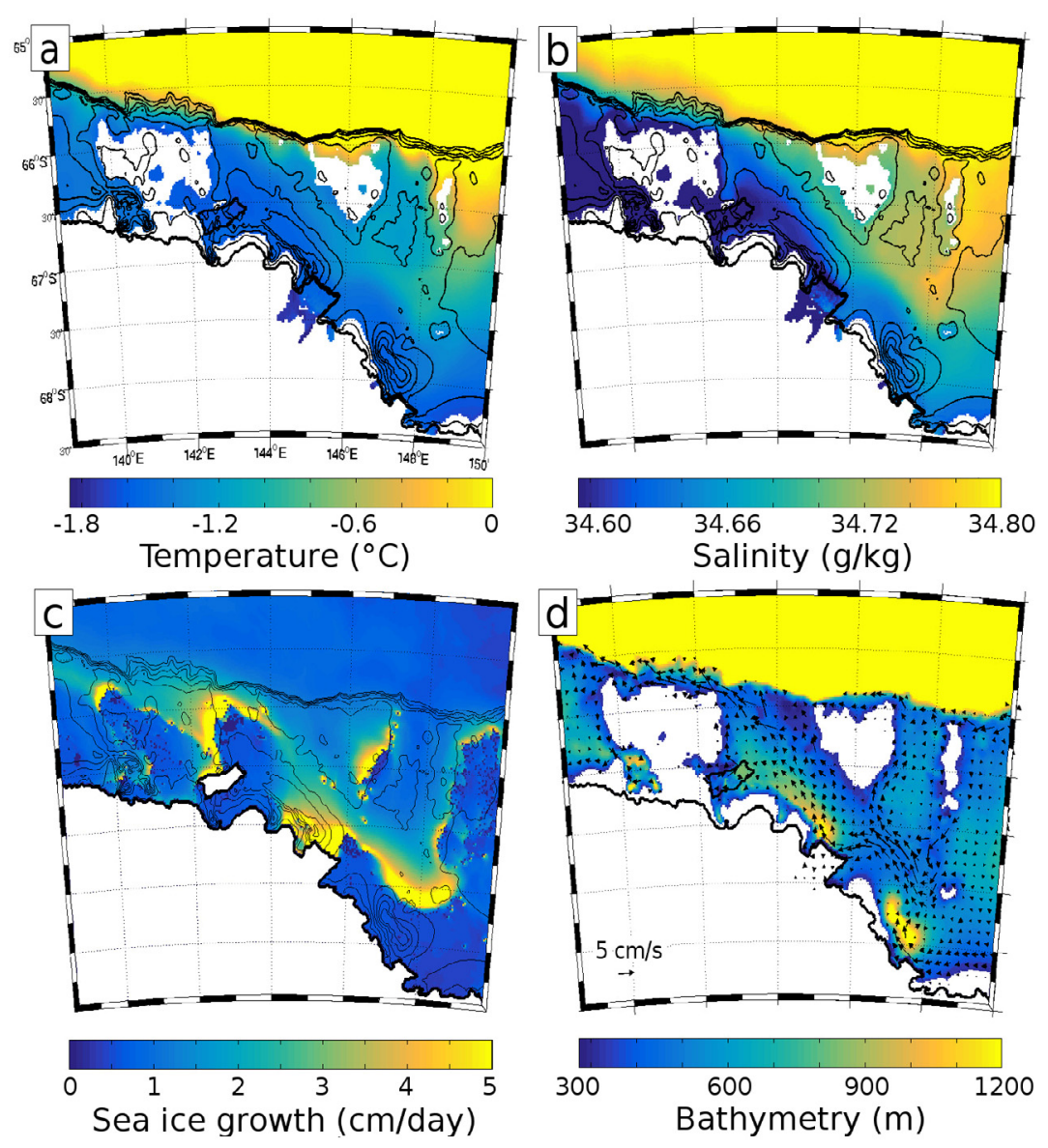

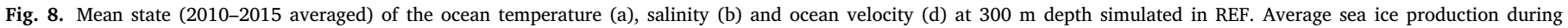
March-October simulated in REF (c). Bathymetry is indicated as black contours every $200 \mathrm{~m}$ in (a), (b), (c) and as color shading in (d).

response to sea ice formation, the water column destratifies. Eventually, the salinity becomes high enough to enable the production of dense water (DSW, potentially converted into MSW after mixing with CDW), suggested by the rise of the $28.27 \mathrm{~kg} / \mathrm{m}^{3}$ neutral density contour. Surface waters reach the dense water state almost every year in the MBP and NGP (Fig. 10c, f), with the exception of year 2010 (and 2014 for the NGP). Despite the important sea ice growth rates in the MGP and B9BP, surface waters only reach the dense water state in 2012 . The summer surface salinity is much lower in these two polynyas than in the three others, which can be one of the reasons for the limited dense water formation. Even if the surface water $\gamma_{n}$ do not reach the dense water state, the $\gamma_{n}=28.27 \mathrm{~kg} / \mathrm{m}^{3}$ contour shoals by 50 to 100 $\mathrm{m}$ in summer or late winter in the MGP and NBP. This indicates that dense water production is still possible thanks to mixing at the base of the mixed layer.

The interannual variability of sea ice production in the polynyas is displayed in panel (a) of Fig. 10. This variability explains an important part of the year to year difference in winter time convection. Large volumes of sea ice are created in 2013 for the NBP, MBP and MGP. During this year, surface water density reach the density threshold in these polynyas. Similarly, 2010 is a year of low sea ice production for most of the polynyas, and the surface salinity remains below the dense water threshold. However, low sea ice production does not necessarily mean that dense water formation is not possible. In 2015, the sea ice production is particularly low for the NBP and NGP, but both polynyas form surface water with $\gamma_{n}>27.28 \mathrm{~kg} / \mathrm{m}^{3}$. In the same way, the high sea surface salinities reached in 2012 in the MGP and B9BP are not associated to particularly large volumes of sea ice being created in these polynyas. Another potentially important factor is the summer salinity which tends to be higher than average in these two polynyas prior to the 2012 convection event.

\subsubsection{Sensitivity of dense water to tides and ocean-ice shelf interactions}

Sea ice production plays a central role in the formation of dense water. Despite the changes in the mean ocean temperature and salinity described previously, the presence of tides and ocean-ice shelf interactions does not significantly affect the sea ice growth off Adélie Land (see supplementary Figure A.7). Changes in sea ice growth rates induced by tides and ocean-ice shelf interactions can locally increase or decrease sea ice production by up to $20 \%$, but these differences compensate each other and are not sufficient to significantly impact the cumulated sea ice production in the polynyas (not shown).

To assess the sensitivity of the water masses budget off Adélie Land to tides and ocean-ice shelf interactions, we compute the transport budget of each water mass across the limits of the polynyas (the water masses used for this computation are those defined in Fig. 5c). Following the methodology of Cougnon et al. (2013), we define the transport budget of a water mass as the difference between the inflow and the outflow of water with the properties of the considered water mass across the boundaries of the polynya. A positive transport budget indicates that the water mass is being exported out of the box (draining the volume of water mass which was either produced or stored in the box), and a negative one indicates either the storage or the destruction of the water mass in the box. Results for each polynya and each simulation are gathered in Fig. 11.

In REF, pure CDW is imported in NGP, MBP and NBP (panels c, $\mathrm{d}$ and e of Fig. 11, respectively). This CDW is potentially transformed in-situ and exported as mCDW, which can latter feed the MGP. Winter Water is exported out of B9BP and MGP (panels a and b of Fig. 11), but has a negative budget in NGP and NBP. The budget of WW in MBP is null, suggesting its direct transformation into other water masses. DSW is exported from MBP, with secondary sources in NBP and MGP. The 

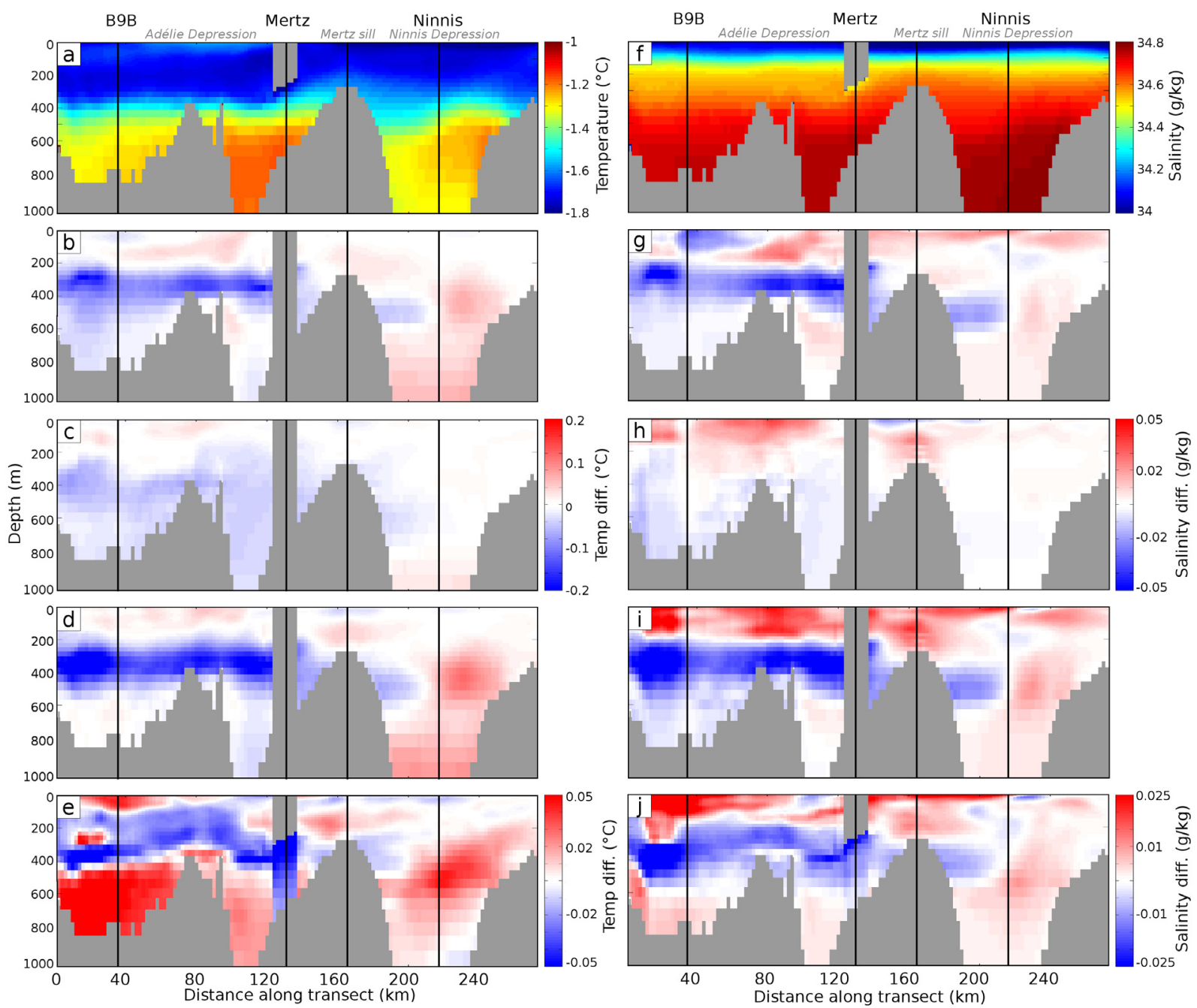

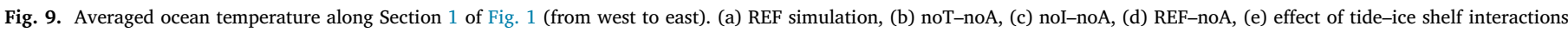

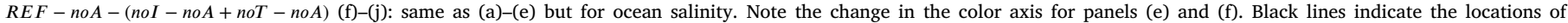
ice shelves or the Mertz Sill.

other type of dense water, namely MSW, is formed in the MBP and NBP after the mixing of local DSW with intruding CDW. MSW is latter exported and stored or consumed in MGP or B9BP.

In the B9BP, MSW has a negative budget in the REF simulation, but not in the other simulations. REF also shows higher export of lighter water masses such as mCDW and AASW than the simulations without tides and/or ocean-ice shelf interactions. REF stands out from the other simulation, indicating that the effect of the interplay between tides and ocean-ice shelf interactions overcomes the effect of each process taken individually. It can still be noted that noI (tides but no ocean-ice shelf interactions) and REF show little difference for the outflow of $\mathrm{mCDW}$ and WW, suggesting that tides significantly contribute to these exchanges. In MGP, the simulations with ocean-ice shelf interactions strongly differ from the two others. The import of MSW and mCDW and the export of AASW and WW only takes place in REF and noT. While the water mass transport budget shares the same sign between these two simulations, rates of export (or import) are higher in REF than in noT. This is in accordance with the intensification of the effect of ocean-ice shelf interactions by tides described earlier. The export of MSW in NGP is highly reduced in both simulations representing ocean-ice shelf interactions. Tides alone (noI) appear to inhibit the outflow of mCDW and the inflow of CDW. The effect of tides on mCDW is compensated when ocean-ice shelf interactions are also accounted for. The water mass transport budget in MBP and NBP are almost unaffected by ocean-ice shelf interactions. This could be expected by their relatively remote location from the ice shelves. When tides are absent (noT and noA), more CDW and WW are imported and the export of mCDW and MSW are slightly increased for MBP.

Tides and ocean-ice shelf interactions affect the water masses transport budget in different ways from one polynya to the other. In the B9B, the effect of ice shelves is weak in the absence of tides but becomes significant when both processes are taken into account. Ocean-ice shelf interactions have an important effect on water mass transport budget in MGP, and this effect is strengthened when tides are accounted for. In NGP, tides and ocean-ice shelf interactions have independent effects which add up when both processes are considered. This analysis illustrates that ocean-ice shelf interactions induce a net decrease of the export of dense waters out of the B9BP, NGP and MGP, and that tides amplify this effect in B9BP and MGP. Ice shelf melting appears to favor the inflow of mCDW, CDW or MSW and to increase the outflow of WW or AASW. The budget of shelf water (DSW and MSW) cumulated over all polynyas is almost null in REF (6.89 mSv), and amounts to 80.1, 62.10 and $73.26 \mathrm{mSv}$ in noI, noT and noA, respectively. These results suggest that ocean-ice shelf interactions can limit the production of dense water or favor its consumption.

The influence of ocean-ice shelf interactions on dense water can be separated in two distinct contributions. First, water masses are directly transformed inside the ice shelf cavity, either by mixing or by the heat and freshwater fluxes at the ice-ocean interface. Then, the water mass 

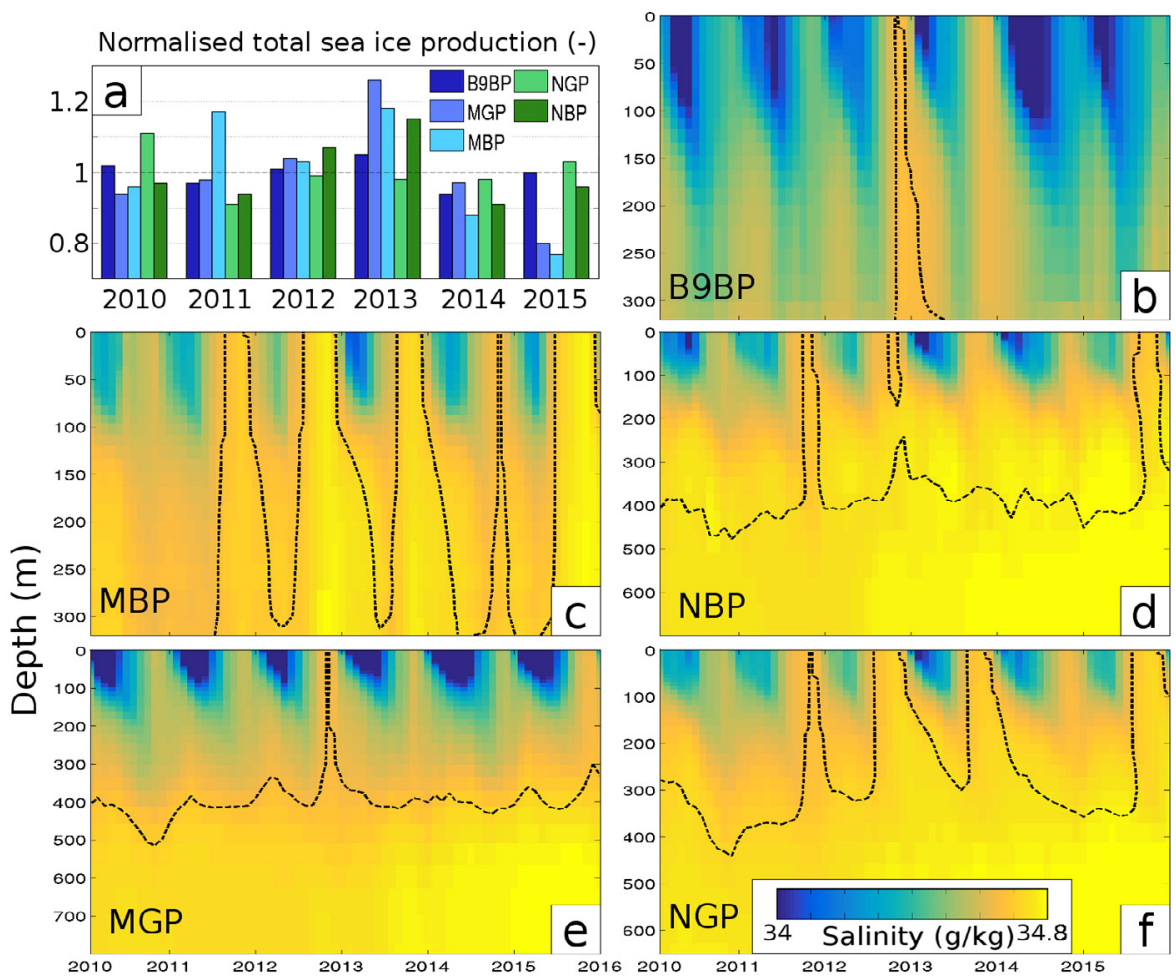

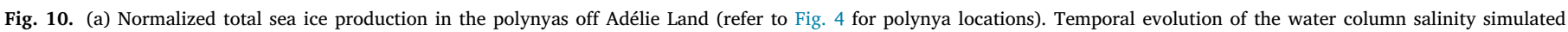
in REF for the B9BP (b), MBP (c), NBP (d), MGP (e) and NGP (f). Dashed black line represents $\gamma_{n}=28.27 \mathrm{~kg} / \mathrm{m}^{3}$ (used to define MSW and DSW).

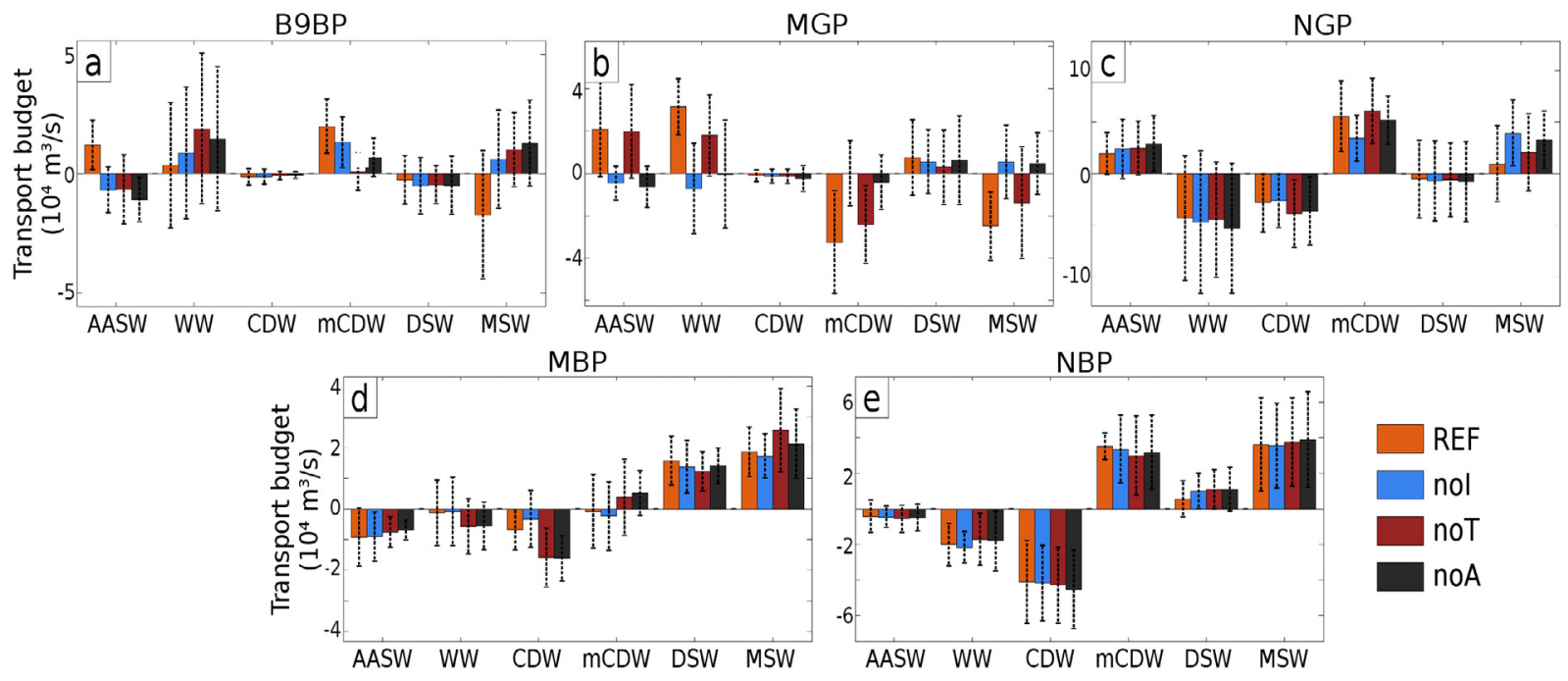

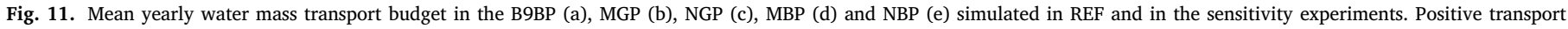
budget rates indicates net export. Black dashed lines indicate interannual standard deviation. Refer to Fig. 4a for polynya locations and Fig. $5 \mathrm{c}$ for water mass definitions.

transformations can also be modified outside the cavity due to the changes in the water column properties (as described in Fig. 9).

To understand how ocean-ice shelf interactions impact the volume of dense water, we compute the water mass transport budget for ice shelf cavities. The average transport budgets in temperature and salinity space are shown in Fig. 12 for the B9B iceberg and Mertz and Ninnis ice shelves. The temperature/salinity diagram is divided in intervals of temperature and salinity with bin widths of $0.08{ }^{\circ} \mathrm{C}$ and $0.05 \mathrm{~g} / \mathrm{kg}$, respectively. The water mass transport budget beneath the ice shelves consists of the import of mCDW and MSW (and lower amount of WW or AASW) and the export of a fresher and cooler water mass. MSW is imported into the three cavities, while mCDW is only entering the Mertz ice shelf cavity. The water masses outflowing from the ice shelf cavities have the properties of high salinity AASW, mCDW or WW for the B9B and Mertz, and MSW or mCDW for Ninnis. In REF, the average cooling amounts to $0.17^{\circ} \mathrm{C}$ for $\mathrm{B} 9 \mathrm{~B}$ and $0.11^{\circ} \mathrm{C}$ for Mertz and Ninnis, while the water masses are freshened by $0.12,0.05$ and $0.03 \mathrm{~g} / \mathrm{kg}$ respectively. A small amount of DSW can also be imported in the Mertz and Ninnis cavities. The basal melt of ice shelves act as a positive buoyancy flux as it reduces the density of the inflowing water masses, leaving the freshening signature observed in the Adélie Depression (see Fig. 9). The total import is higher in the presence of tides, as ice shelf basal melt is higher. REF exhibits an increase in basal melt-driven inflow of $45 \%$ for B9B, $21 \%$ for Mertz and $16 \%$ for Ninnis with respect to noT. On average, dense water inflow and potential transformation beneath ice 


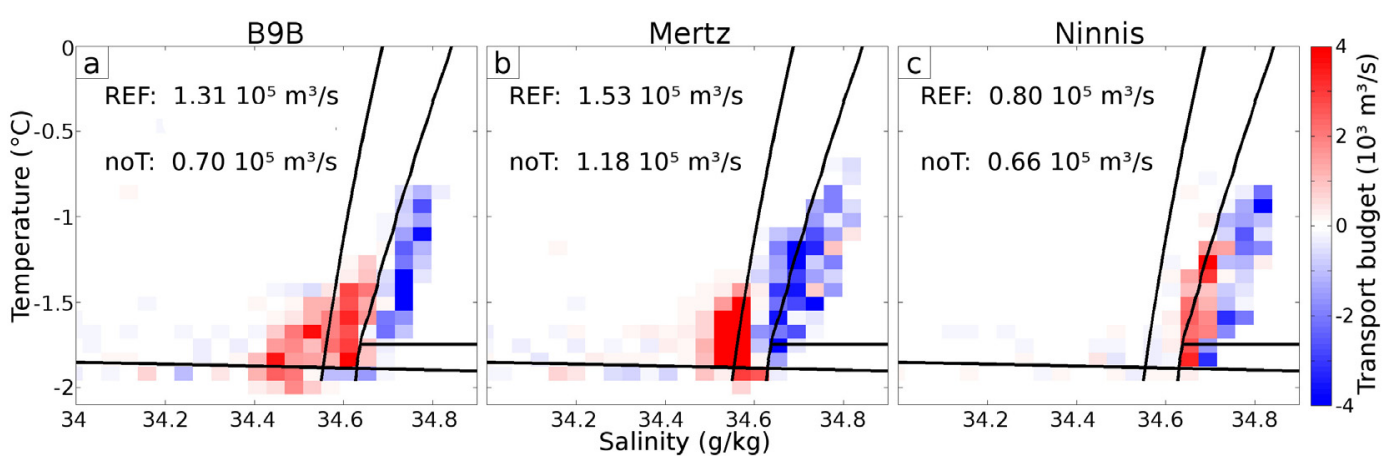

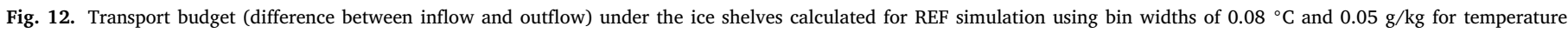

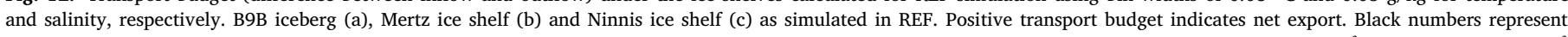

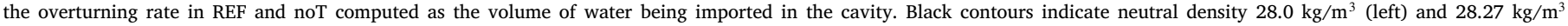
(right). Bottom black lines indicate freezing point of surface temperature and $\mathrm{T}=-1.75{ }^{\circ} \mathrm{C}$.

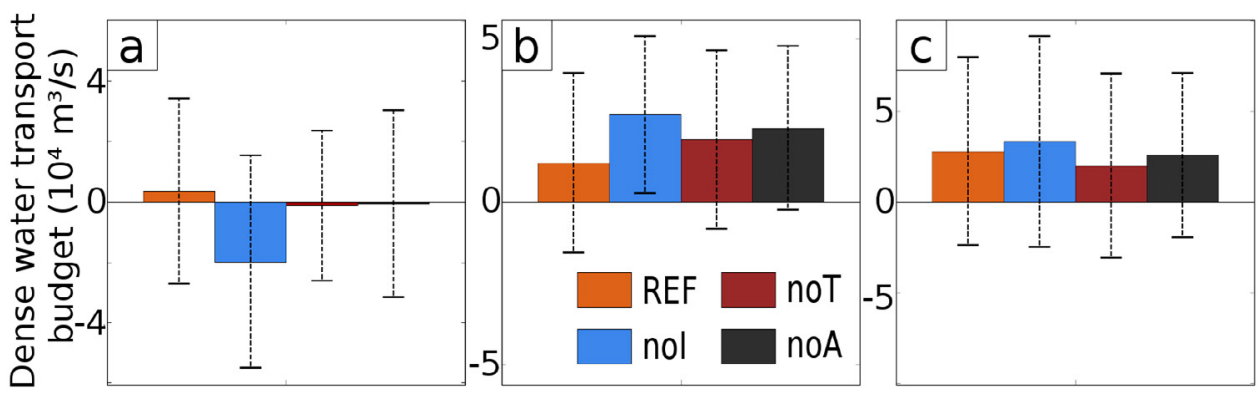

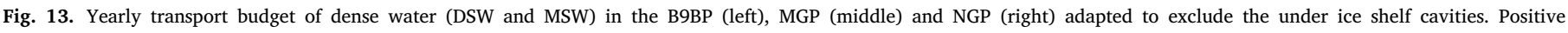
transport budget indicates net export. Black lines indicate the interannual standard deviation.

shelf cavities amounts to $9.2(6.7) \mathrm{mSv}$ in B9BP, $28.6(22.2) \mathrm{mSv}$ in MGP and 24.4 (11.1) $\mathrm{mSv}$ in NGP in REF (respectively noT).

The changes in the water column properties or ocean circulation due to ocean-ice shelf interactions may affect the formation of DSW outside the cavities. To investigate this effect, the water mass transport budgets were computed in boxes 1, 2 and 5 (Fig. 1) reshaped to exclude the ice shelves. By this way, we ensure that the water mass transformations accounted for are only the ones happening in the polynyas. The yearly transport budgets of dense water (DSW and MSW) are displayed in Fig. 13. When considering only the polynyas (and not the processes happening beneath the ice shelf cavities), the transport budget of dense water simulated in REF is almost null in B9BP, and a net export is found for MGP and NGP. In the B9BP, only noI shows a significant departure from REF, with an important inflow of dense water. As noT does not differ from noA, this indicates that ocean-ice shelf interactions alone have little impact. However, since REF includes tides and its dense water transport budget is almost null, it appears that the effect of the tide-induced basal melt counteracts the effect of tides alone. Dense water exports from the MGP are the lowest in REF and noT, i.e., when ocean-ice shelf interactions are present. REF shows a lower export than noT, indicating that the intensification of the effect of ice shelf basal melt by tides exceeds the slight positive effect of tides alone (noI vs noA). On the contrary, in the NGP, the dense water export in REF shows no difference with noA, indicating a compensation of the negative effect of ocean-ice shelf interactions (noT $v$ noA) by the positive effect of tides (noI vs noA).

Overall, the remote effect of ocean-ice shelf interactions slightly reduces dense water export from MGP and NGP. The water mass transport budget showed larger sensitivity to ocean-ice shelf interactions when the ice shelf cavities were included in the boxes used for the diagnostic. This indicates that most of the effect of ocean-ice shelf interactions on dense water transport budget takes place inside the ice shelf cavities.

\section{Discussion}

The production of DSW off Adélie Land has undergone an important decline after the calving of the Mertz Ice Tongue in 2010. While the diminution of sea ice growth is most likely the first driver of this decrease, the potential role of other processes is not well understood. In this study, we tested the hypothesis that ocean-ice shelf interactions and tides can modify the water mass budget and the export of dense water. We show that ocean-ice shelf interactions destratify the upper $500 \mathrm{~m}$ of the water column, leaving a fresh and cold anomaly between depths of 200 and $500 \mathrm{~m}$ and a warming and salinity increase in the top $200 \mathrm{~m}$. This effect is enhanced in the presence of tides, in response to higher ice shelf basal melt. Ocean-ice shelf interactions lower the volume of dense water off Adélie Land in two ways: through the conversion of dense water into water masses with intermediate density in the ice shelf cavities and by limiting the export of dense water out of the polynyas.

The basal melt of the ice shelves off Adélie Land is found to be highly sensitive to tides, with a positive dynamical forcing partly compensated by a negative thermal one. This sensitivity arises from the relatively high magnitude of tidal velocities in the region (especially for the B9B). Such results were already obtained in previous studies such as Jourdain et al. (2019) for West Antarctica and Hausmann et al. (2020) for the Ronne ice shelf. However, our results indicate that tides considered alone have little impact on the ocean and sea ice in the eastern D'Urville Sea. Stewart et al. (2018) suggested that tides play an important role in the intrusions of CDW onto the continental shelves. They showed, however, that this effect was highly variable from one place to the other and can be absent from several portions of the Antarctic continental shelf break. In our simulations, tides favor the cross-shelf intrusions of CDW west of the Adélie Bank (west of $140^{\circ}$ E) but have little impact over the section studied here (between $140^{\circ}$ E- $150^{\circ}$ E). Most of the effect of tides for the eastern D'Urville Sea resides in their interactions with ice shelves. An important implication 
of this result is that tides strongly amplify the effect of ocean-ice shelf interactions. The role played by tides in coastal seas of Antarctica might thus have been overlooked in previous studies where ocean-ice shelf interactions were not considered.

Ice shelf-ocean interactions lower the export of dense waters (MSW or DSW) out of the polynyas of Adélie Land. While this result is in accordance with several previous studies (Cougnon et al., 2013; De Lavergne et al., 2014; Silvano et al., 2018), the mechanism being involved seems different in our simulations. These authors indeed argued that the input of freshwater led to a lowering of the maximum density of the winter water. In our simulations, this process seems to takes place in the MGP, but not in the NGP and B9BP. A potential explanation for this difference is the rise in the salinity of the top $200 \mathrm{~m}$ of the ocean induced by ocean-ice shelf interactions. A similar increase in near-surface salinity was obtained by Mathiot et al. (2017) and was attributed to the upwelling of $\mathrm{mCDW}$ or SW by the basalmelt-driven overturning. In our simulations, the principal factor for the decline in dense water formation appears to be the conversion of those dense waters (especially MSW) into lighter water masses at the ice shelf-ocean interface. We demonstrated here that ice shelf-induced conversion of dense water can substantially affect the dense water budget off Adélie Land. This illustrates the importance of representing under ice shelf cavities in climate models. Another approach consists of applying the freshwater flux from the ice shelf in the subsurface, in order to mimic the effect of the cavities without explicitly representing them. This methodology, proposed by Mathiot et al. (2017) is for instance used in some CMIP6 models (Storkey et al., 2018; Lurton et al., 2020) and might be able to reproduce the effect of the ocean-ice shelf interactions on dense water.

The influence of ocean-ice shelf interactions on the dense water export off Adélie Land confirms the hypothesis that changes in basal melt could be one of the driving mechanisms for dense water production variability. As mentioned earlier, the volume and density of dense water produced in Adélie Land underwent a significant decline following the Mertz calving and B9B relocation (Lacarra et al., 2014; Snow et al., 2016; Aoki et al., 2017). While the observed changes in sea ice production estimated by Tamura et al. (2012) are certainly the main driver of these modifications, we advocate that other processes might also be involved, such as changes in ice shelf basal melt. Modeling studies of Kusahara et al. (2017) and Cougnon et al. (2017) (hereafter K17 and C17) proposed a distinct response to the calving: K17 suggested a decrease in the Mertz basal melt, while C17 advocated the opposite. In our work, only the post-calving scenario is considered, but it can complement the two aforementioned studies. Both C17 and K17 found an increase in mCDW intrusions east of the Mertz Sill (east of $146^{\circ} \mathrm{E}$ ), which lead to a warming in the Adélie depression in C17 but not in K17. K17 and C17 both represent ocean-ice shelf interactions, but only the model of C17 incorporates tides and a velocity dependent basal melt parameterization (similarly to our model). Another difference is the bathymetry and ice draft dataset used in these studies. The K17 model does not include the recent measurements of Beaman et al. (2011), and their ice shelf drafts show important differences with the recent dataset used in this study or in C17, especially for the Mertz ice shelf. The mean ocean state simulated here resembles the post-calving state of $\mathrm{C} 17$, especially considering the intrusions of $\mathrm{mCDW}$ in the Adélie depression. Our results seem to support the finding of C17, namely an increase in ice shelf basal melt, but this must be regarded with caution knowing the uncertainties that remains about the ice shelf draft and bathymetry of the region. The actual changes in ice shelf basal melt post-calving remains to be supported by observations. Under the hypothesis that the basal melt of the Mertz ice shelf increased following the calving, our results suggest that this might be one of the reason for the dense water production decrease.

The present study faces some limitations. The first one resides in the properties of the water masses simulated in the Adélie Depression. As depicted in Fig. 5, our simulations exhibit a warm bias of $0.5{ }^{\circ} \mathrm{C}$ with respect to in-situ CTD casts there. The presence of MSW instead of DSW in the deep Adélie Shelf Sea can affect the ice shelf basal melt and its effect on the SW production. In presence of colder DSW, the basal melt should be weakened, which could reduce the effect of the ocean-ice shelf interactions on the consumption of SW. The interannual variability of the simulated ice shelf melt can be used to explore the sensitivity of the ice shelf melt to the ocean forcing, and the impact on water masses. The basal melt of the ice shelves is $140 \%$ lower during years 2008, 2009 and 2012 (1.37 Gt/yr for the Mertz in REF) than during years 2010, 2014 and 2015 (3.32 Gt/yr for the Mertz). This is most likely due to the thermal forcing of the ocean, since the averaged temperature in the cavity is below $-1.7^{\circ} \mathrm{C}$ during years of low basal melt rate (supplementary Figure A.10a). During these periods, the basal melt driven consumption of SW simulated in REF is $160 \%$ lower than during the periods of intense basal melt (supplementary Figure A.10b). The transformations of SW inside the cavity seem to be highly sensitive to the basal melt rate. Another effect of the presence of MSW instead of DSW is linked to the non-linearities of the seawater equation of state. The transformation of DSW by ocean-ice shelf interactions can be estimated to be $30 \%$ higher than the transformation of MSW for a similar basal melt rate (see supplementary Figure A.10c), due to the increase in sea water density with decreasing temperature. Additionally, the warm anomaly can limit the sea ice growth as the mixed layer deepens during winter, potentially responsible for the low sea ice production rate in MBP and NBP.

This warm bias might be induced by the mean circulation simulated by our model: the westward current crossing the Mertz Sill and Adélie Depression carries large amount of relatively warm mCDW. Such intrusions of mCDW have been suggested by Snow et al. (2016) and Martin et al. (2017) before the calving, but the amount of mCDW entering the Adélie Depression through the Mertz Sill are unknown in the current state. Summer observations, however, indicate intrusions of CDW east of the Mertz Sill (Aoki et al., 2017), without entering the Adélie Depression. Understanding the driving mechanism of the CDW intrusions east of the Adélie Depression is beyond the scope of this study. It also appears that the destratification in the Adélie Depression remains incomplete by the end of winter. One could expect to obtain different ocean-ice shelf interactions and impact on polynyas if the stratification is entirely eroded each winter. One potential cause resides in the atmospheric forcing resolution: despite the relatively high resolution of the ERA5 dataset $(31 \mathrm{~km})$, it is probably not enough to catch the detailed topography which leads to the exceptional intensity of katabatic winds in Adélie Land (as do most of the global atmospheric reanalysis (Jones et al., 2016; Jonassen et al., 2019). This can have the effect of underestimating the actual sea ice production in coastal polynyas. In addition to the low sea ice production, the presence of the B9B iceberg during our simulated period potentially further limits the formation of DSW (K17 simulated sustained sea ice growth over larger portions of the Adélie Depression as the B9B is absent). One could expect higher DSW formation rate now that the B9B has left the Adélie Depression. Finally, the method used here to analyze the influence of ocean-ice shelf interactions on dense water (namely the transport budget) presents some limitations. It is not suited to discriminate between thermodynamical water mass transformation and local convergence/divergence of water mass. Other methods, such as the one proposed by Abernathey et al. (2016) or Jeong et al. (2020) could solve this issue.

\section{Conclusion}

In this study, we analyzed the sensitivity of ice shelf basal melt, ocean mean state and dense water transport to the representation of tides and ice shelves. We run a series of high-resolution simulations of the ocean and sea ice using an ocean-sea ice model driven by atmospheric reanalysis. Our experiments revealed that ice shelves of the D'Urville Sea are highly sensitive to tidal forcing, with a basal 
melt increase ranging from $+62 \%$ to $+250 \%$ depending on the ice shelf considered. This response is attributed to the dynamical forcing of tides near ocean-ice shelf interface. Ocean-ice shelf interactions yield a cooling and a freshening of the subsurface ocean, and a warming and salinity increase concentrated in the top $200 \mathrm{~m}$ of the water column, and to the onset of a basal-melt-driven circulation. The investigation of water mass transport in polynyas revealed that the Mertz Glacier Polynya hosts very little dense water formation, but that DSW can be formed in other polynyas off Adélie Land (Mertz or Ninnis Bank Polynyas). The heat and freshwater fluxes between ice and ocean beneath ice shelves yield a freshening and cooling of the water masses involved (mCDW, CDW, MSW or DSW). This results in the production of a relatively light water mass from the consumption of dense water (mostly MSW). This way, ocean-ice shelf interactions lead to a decrease in the amount of dense water being formed off Adélie Land, as part of the dense water formed in situ is consumed beneath ice shelves. This effect is further strengthened by tide-induced ice shelf basal melt increase. Moreover, the subsurface freshening induced by ice shelf melting inhibits the conversion of surface waters into dense waters as sea ice forms. This suggests that ocean-ice shelf interactions could have played a role in recent changes of dense water formation. Tides and ocean-ice shelf interactions are two important processes that have to be accounted for in numerical models dedicated to the study of formation of dense water. Furthermore, we argue that both processes have to be represented together as the absence of interactions between them might alter results from studies involving tides or ice shelves in coastal Antarctica. The importance of ice shelves for dense water transformation raises the question of the formation of DSW in a future climate. Our results suggest that an increase in ice shelf basal melt could lead to a diminution of dense water production. The important interactions between ice shelf basal melt in the presence of tides stress the need to take these processes into account in climate models.

\section{CRediT authorship contribution statement}

Pierre-Vincent Huot: Conceptualization, Formal analysis, Investigation, Methodology, Software, Writing - original draft, Writing review \& editing, Visualization. Thierry Fichefet: Conceptualization, Funding acquisition, Supervision, Writing - revision and editing. Nicolas C. Jourdain: Conceptualization, Methodology, Writing - review and editing. Pierre Mathiot: Methodology, Writing - review and editing. Clément Rousset: Methodology, Writing - review and editing. Christoph Kittel: Writing - review and editing. Xavier Fettweis: Supervision, Funding acquisition, Writing - review and editing.

\section{Declaration of competing interest}

The authors declare that they have no known competing financial interests or personal relationships that could have appeared to influence the work reported in this paper.

\section{Acknowledgments}

The authors are thankful to the four anonymous reviewers for their very valuable remarks and advice which certainly helped to improve this manuscript. This research was conducted within the F.R.S.FNRS PDR T.0002.16 "Air-Ice-Ocean Interactions in Antarctica" and the PARAMOUR project, funded by the FWO and F.R.S.-FNRS under the Excellence of Science (EOS) programme (grant EOS O0100718F). Computational resources have been provided by the supercomputing facilities of the Université catholique de Louvain (CISM/UCL) and the Consortium des Équipements de Calcul Intensif en Fédération Wallonie Bruxelles (CÉCI) funded by the Fond de la Recherche Scientifique de Belgique (F.R.S.-FNRS) under convention 2.5020.11. The present research benefited from computational resources made available on the Tier-1 supercomputer of the Fédération Wallonie-Bruxelles, infrastructure funded by the Walloon Region, Belgium under the Grant Agreement No. 1117545. The authors acknowledge the JWCRP Joint Marine Modeling Programme for providing support.

\section{Appendix A. Supplementary data}

Supplementary material related to this article can be found online at https://doi.org/10.1016/j.ocemod.2021.101794.

\section{References}

Abernathey, R.P., Cerovecki, I., Holland, P.R., Newsom, E., Mazloff, M., Talley, L.D., 2016. Water-mass transformation by sea ice in the upper branch of the Southern Ocean overturning. Nat. Geosci. 9, 596-601.

Adusumilli, S., Fricker, H.A., Medley, B., Padman, L., Siegfried, M.R., 2020. Interannual variations in meltwater input to the Southern Ocean from Antarctic ice shelves. Nat. Geosci. 13, 616-620.

Alley, R.B., Clark, P.U., Huybrechts, P., Joughin, I., 2005. Ice-sheet and sea-level changes. Science 310, 456-460.

Aoki, S., Kobayashi, R., Rintoul, S., Tamura, T., Kusahara, K., 2017. Changes in water properties and flow regime on the continental shelf off the Adélie/George VL and coast, East Antarctica, after glacier tongue calving. J. Geophys. Res.: Oceans 122, 6277-6294.

Aoki, S., Rintoul, S.R., Ushio, S., Watanabe, S., Bindoff, N.L., 2005. Freshening of the Adélie Land Bottom water near 140 E. Geophys. Res. Lett. 32.

Aoki, S., Yamazaki, K., Hirano, D., Katsumata, K., Shimada, K., Kitade, Y., Sasaki, H., Murase, H., 2020. Reversal of freshening trend of Antarctic Bottom Water in the Australian-Antarctic Basin during 2010s. Sci. Rep. 10, 1-7.

Arzeno, I.B., Beardsley, R.C., Limeburner, R., Owens, B., Padman, L., Springer, S.R., Stewart, C.L., Williams, M.J., 2014. Ocean variability contributing to basal melt rate near the ice front of Ross Ice Shelf, Antarctica. J. Geophys. Res.: Oceans 119, 4214-4233.

Beaman, R.J., O’Brien, P.E., Post, A.L., De Santis, L., 2011. A new high-resolution bathymetry model for the Terre Adéie and George V continental margin, East Antarctica. Antarct. Sci. 23, 95-103.

Berthier, E., Raup, B., Scambos, T., 2003. New velocity map and mass-balance estimate of Mertz Glacier, East Antarctica, derived from Landsat sequential imagery. J. Glaciol. 49, 503-511.

Bintanja, R., Van Oldenborgh, G., Katsman, C., 2015. The effect of increased fresh water from Antarctic ice shelves on future trends in Antarctic sea ice. Ann. Glaciol. 56, $120-126$.

Boucher, O., Servonnat, J., Albright, A.L., Aumont, O., Balkanski, Y., Bastrikov, V., Bekki, S., Bonnet, R., Bony, S., Bopp, L., et al., 2020. Presentation and evaluation of the IPSL-CM6a-LR climate model. J. Adv. Modelling Earth Syst. 12, 1-52.

Bougeault, P., Lacarrere, P., 1989. Parameterization of orography-induced turbulence in a mesobeta-scale model. Mon. Weather Rev. 117, 1872-1890.

Bronselaer, B., Winton, M., Griffies, S.M., Hurlin, W.J., Rodgers, K.B., Sergienko, O.V., Stouffer, R.J., Russell, J.L., 2018. Change in future climate due to Antarctic meltwater. Nature 564, 53-58.

Cabanes, C., Grouazel, A., Schuckmann, K.v., Hamon, M., Turpin, V., Coatanoan, C., Paris, F., Guinehut, S., Boone, C., Ferry, N., et al., 2013. The CORA dataset: validation and diagnostics of in-situ ocean temperature and salinity measurements. Ocean Sci. 9, 1-18.

Carrère, L., Lyard, F., Cancet, M., Guillot, A., Roblou, L., 2012. A new global tidal model taking taking advantage of nearly 20 years of altimetry. In: Proceedings of Meeting 20 Years of Altimetry.

Cougnon, E., Galton-Fenzi, B., Meijers, A., Legrésy, B., 2013. Modeling interannual dense shelf water export in the region of the Mertz Glacier Tongue (1992-2007). J. Geophys. Res.: Oceans 118, 5858-5872.

Cougnon, E., Galton-Fenzi, B., Rintoul, S., Legrésy, B., Williams, G., Fraser, A., Hunter, J., 2017. Regional changes in icescape impact shelf circulation and basal melting. Geophys. Res. Lett. 44.

Curry, J.A., Schramm, J.L., Ebert, E.E., 1995. Sea ice-albedo climate feedback mechanism. J. Clim. 8, 240-247.

De Lavergne, C., Palter, J.B., Galbraith, E.D., Bernardello, R., Marinov, I., 2014. Cessation of deep convection in the open Southern Ocean under anthropogenic climate change. Nature Clim. Change 4, 278.

Depoorter, M.A., Bamber, J., Griggs, J., Lenaerts, J.T., Ligtenberg, S.R., van den Broeke, M.R., Moholdt, G., 2013. Calving fluxes and basal melt rates of Antarctic ice shelves. Nature 502, 89.

Donlon, C.J., Martin, M., Stark, J., Roberts-Jones, J., Fiedler, E., Wimmer, W., 2012. The operational sea surface temperature and sea ice analysis (OSTIA) system. Remote Sens. Environ. 116, 140-158.

Engedahl, H., 1995. Use of the flow relaxation scheme in a three-dimensional baroclinic ocean model with realistic topography. Tellus A 47, 365-382.

EUMETSAT, 2015. Global sea ice concentration reprocessing data- set 1978-2015 (v1.2).

Flather, R.A., 1994. A storm surge prediction model for the northern Bay of Bengal with application to the cyclone disaster in April 1991. J. Phys. Oceanogr. 24, 172-190.

Fogwill, C., Phipps, S., Turney, C., Golledge, N., 2015. Sensitivity of the Southern Ocean to enhanced regional Antarctic ice sheet meltwater input. Earth's Future 3, 317-329. 
Fraser, A.D., Massom, R.A., Michael, K.J., Galton-Fenzi, B.K., Lieser, J.L., 2012. East Antarctic landfast sea ice distribution and variability, 2000-08. J. Clim. 25, 1137-1156.

Fretwell, P., Pritchard, H.D., Vaughan, D.G., Bamber, J., Barrand, N., Bell, R., Bianchi, C., Bingham, R., Blankenship, D.D., Casassa, G., et al., 2013. Bedmap2: improved ice bed, surface and thickness datasets for Antarctica.

Gaspar, P., Grégoris, Y., Lefevre, J.M., 1990. A simple Eddy kinetic energy model for simulations of the oceanic vertical mixing: Tests at station Papa and Long-Term Upper Ocean Study site. J. Geophys. Res.: Oceans 95, 16179-16193.

Golledge, N.R., Keller, E.D., Gomez, N., Naughten, K.A., Bernales, J., Trusel, L.D., Edwards, T.L., 2019. Global environmental consequences of twenty-first-century ice-sheet melt. Nature 566, 65-72.

Hallberg, R., 2013. Using a resolution function to regulate parameterizations of oceanic mesoscale Eddy effects. Ocean Model. 72, 92-103.

Hausmann, U., Sallée, J.B., Jourdain, N., Mathiot, P., Rousset, C., Madec, G., Deshayes, J., Hattermann, T., 2020. The role of tides in ocean-ice-shelf interactions in the southwestern Weddell Sea. J. Geophys. Res.: Oceans e2019JC015847.

Held, I., Guo, H., Adcroft, A., Dunne, J., Horowitz, L., Krasting, J., Shevliakova, E., Winton, M., Zhao, M., Bushuk, M., et al., 2019. Structure and performance of GFDL's CM4. 0 climate model. J. Adv. Modelling Earth Syst. 11, 3691-3727.

Hersbach, H., Bell, B., Berrisford, P., Hirahara, S., Horányi, A., Muñoz Sabater, J., Nicolas, J., Peubey, C., Radu, R., Schepers, D., et al., 2020. The ERA5 global reanalysis. Q. J. R. Meteorol. Soc. 146, 1999-2049.

Heuzé, C., 2020. Antarctic bottom water and north Atlantic deep water in CMIP6 models. Ocean Sci. Discuss. 1-38.

Heuzé, C., Heywood, K.J., Stevens, D.P., Ridley, J.K., 2013. Southern Ocean bottom water characteristics in CMIP5 models. Geophys. Res. Lett. 40, 1409-1414.

Jacobs, S.S., 2004. Bottom water production and its links with the thermohaline circulation. Antarct. Sci. 16, 427-437.

Jenkins, A., 1991. A one-dimensional model of ice shelf-ocean interaction. J. Geophys. Res.: Oceans 96, 20671-20677.

Jeong, H., Asay-Davis, X.S., Turner, A.K., Comeau, D.S., Price, S.F., Abernathey, R.P., Veneziani, M., Petersen, M.R., Hoffman, M.J., Mazloff, M.R., et al., 2020. Impacts of ice-shelf melting on water-mass transformation in the southern ocean from E3SM simulations. J. Clim. 33, 5787-5807.

Johnson, G.C., 2008. Quantifying Antarctic bottom water and North Atlantic deep water volumes. J. Geophys. Res.: Oceans 113.

Jonassen, M.O., Välisuo, I., Vihma, T., Uotila, P., Makshtas, A.P., Launiainen, J., 2019. Assessment of atmospheric reanalyses with independent observations in the Weddell Sea, the Antarctic. J. Geophys. Res.: Atmos. 124, 12468-12484.

Jones, R.W., Renfrew, I.A., Orr, A., Webbeg, B.G.M., Holland, D.M., Lazzaea, M.A., 2016. Evaluation of four global reanalysis products using in situ observations in the Amundsen Sea Embayment, Antarctica. J. Geophys. Res.: Atmos. 121, 6240-6257.

Jourdain, N.C., Mathiot, P., Merino, N., Durand, G., Le Sommer, J., Spence, P., Dutrieux, P., Madec, G., 2017. Ocean circulation and sea-ice thinning induced by melting ice shelves in the Amundsen Sea. J. Geophys. Res.: Oceans 122, 2550-2573.

Jourdain, N.C., Molines, J.M., Le Sommer, J., Mathiot, P., Chanut, J., de Lavergne, C., Madec, G., 2019. Simulating or prescribing the influence of tides on the Amundsen Sea ice shelves. Ocean Model. 133, 44-55.

Jungclaus, J., Fischer, N., Haak, H., Lohmann, K., Marotzke, J., Matei, D., Mikolajewicz, U., Notz, D., Von Storch, J., 2013. Characteristics of the ocean simulations in the Max Planck Institute Ocean Model (MPIOM) the ocean component of the MPI-Earth system model. J. Adv. Modelling Earth Syst. 5, 422-446.

Kaleschke, L., Lüpkes, C., Vihma, T., Haarpaintner, J., Bochert, A., Hartmann, J., Heygster, G., 2001. SSM/I sea ice remote sensing for mesoscale ocean-atmosphere interaction analysis. Can. J. Remote Sens. 27, 526-537.

Koentopp, M., Eisen, O., Kottmeier, C., Padman, L., Lemke, P., 2005. Influence of tides on sea ice in the Weddell Sea: Investigations with a high-resolution dynamic-thermodynamic sea ice model. J. Geophys. Res.: Oceans 110.

Kusahara, K., Hasumi, H., Fraser, A.D., Aoki, S., Shimada, K., Williams, G.D., Massom, R., Tamura, T., 2017. Modeling ocean-cryosphere interactions off Adéie and George V land, East Antarctica. J. Clim. 30, 163-188. http://dx.doi.org/10.1175/ jcli-d-15-0808.1.

Kusahara, K., Hasumi, H., Tamura, T., 2010. Modeling sea ice production and dense shelf water formation in coastal polynyas around East Antarctica. J. Geophys. Res. 115, http://dx.doi.org/10.1029/2010jc006133.

Kusahara, K., Hasumi, H., Williams, G.D., 2011. Impact of the Mertz Glacier Tongue calving on dense water formation and export. Nat. Commun. 2, 159.

Lacarra, M., Houssais, M.N., Herbaut, C., Sultan, E., Beauverger, M., 2014. Dense shelf water production in the Adé Depression, East Antarctica, 2004-2012: Impact of the Mertz Glacier calving. J. Geophys. Res.: Oceans 119, 5203-5220. http: //dx.doi.org/10.1002/2013jc009124.

Large, W.G., Yeager, S.G., 2004. Diurnal to decadal global forcing for ocean and sea-ice models: the data sets and flux climatologies.

Lavergne, T., Sørensen, A.M., Kern, S., Tonboe, R., Notz, D., Aaboe, S., Bell, L., Dybkjær, G., Eastwood, S., Gabarro, C., et al., 2019. Version 2 of the EUMETSAT OSI SAF and ESA CCI sea-ice concentration climate data records. Cryosphere 13, 49-78.

Lemieux, J.F., Dupont, F., Blain, P., Roy, F., Smith, G.C., Flato, G.M., 2016. Improving the simulation of landfast ice by combining tensile strength and a parameterization for grounded ridges. J. Geophys. Res.: Oceans 121, 7354-7368.
Locarnini, R., Mishonov, A., Antonov, J., Boyer, T., Garcia, H., Baranova, O., Zweng, M., Paver, C., Reagan, J., Johnson, D., Hamilton, M., Seidov, D., 2013. World Ocean Atlas2013, Vol. 1: Temperature. NOAA Atlas NESDIS 73.

Locarnini, R., Mishonov, A., Baranova, O., Boyer, T., Zweng, M., Garcia, H., Reagan, J., Seidov, D., Weathers, K., Paver, C., Smolyar, I., 2018. World Ocean Atlas 2018, Vol. 1: Temperature. NOAA Atlas NESDIS 81.

Losch, M., 2008. Modeling ice shelf cavities in azcoordinate ocean general circulation model. J. Geophys. Res. 113, http://dx.doi.org/10.1029/2007jc004368.

Luneva, M.V., Aksenov, Y., Harle, J.D., Holt, J.T., 2015. The effects of tides on the water mass mixing and sea ice in the Arctic Ocean. J. Geophys. Res.: Oceans 120, 6669-6699. http://dx.doi.org/10.1002/2014jc010310.

Lurton, T., Balkanski, Y., Bastrikov, V., Bekki, S., Bopp, L., Braconnot, P., Brockmann, P., Cadule, P., Contoux, C., Cozic, A., et al., 2020. Implementation of the CMIP6 forcing data in the IPSL-CM6A-LR model. J. Adv. Modelling Earth Syst. 12, e2019MS001940.

Madec, G., 2016. NEMO ocean engine. In: Note du Pôle de modélisation. Institut Pierre-Simon Laplace (IPSL), France, No 27, (ISSN: 1288-1619).

Makinson, K., Holland, P.R., Jenkins, A., Nicholls, K.W., Holland, D.M., 2011. Influence of tides on melting and freezing beneath Filchner-Ronne Ice Shelf, Antarctica. Geophys. Res. Lett. 38, http://dx.doi.org/10.1029/2010g1046462, n/a-n/a.

Mantyla, A.W., Reid, J.L., 1983. Abyssal characteristics of the World Ocean waters. Deep-Sea Res. A 30, 805-833.

Maraldi, C., Chanut, J., Levier, B., Ayoub, N., De Mey, P., Reffray, G., Lyard, F., Cailleau, S., Drévillon, E., et al., 2013. NEMO on the shelf: assessment of the Iberia-Biscay-Ireland configuration.

Martin, A., Houssais, M.N., Goff, H.L., Marec, C., Dausse, D., 2017. Circulation and water mass transports on the East Antarctic shelf in the Mertz Glacier region. Deep-Sea Res. I 126, 1-20. http://dx.doi.org/10.1016/j.dsr.2017.05.007.

Massom, R., Harris, P., Michael, K.J., Potter, M., 1998. The distribution and formative processes of latent-heat polynyas in East Antarctica. Ann. Glaciol. 27, 420-426.

Mathiot, P., Barnier, B., Gallée, H., Molines, J.M., Sommer, J.L., Juza, M., Penduff, T., 2010. Introducing katabatic winds in global ERA40 fields to simulate their impacts on the Southern Ocean and sea-ice. Ocean Model. 35, 146-160. http://dx.doi.org/ 10.1016/j.ocemod.2010.07.001.

Mathiot, P., Jenkins, A., Harris, C., Madec, G., 2017. Explicit representation and parametrised impacts of under ice shelf seas in the $\mathrm{z}^{*}$ coordinate ocean model NEMO 3.6. Geosci. Model Dev. 10, 2849-2874. http://dx.doi.org/10.5194/gmd10-2849-2017.

Mathiot, P., Jourdain, N.C., Barnier, B., Gallée, H., Molines, J.M., Sommer, J.L., Penduff, T., 2012. Sensitivity of coastal polynyas and high-salinity shelf water production in the Ross Sea, Antarctica, to the atmospheric forcing. Ocean Dyn. 62, 701-723. http://dx.doi.org/10.1007/s10236-012-0531-y.

Mauritsen, T., Bader, J., Becker, T., Behrens, J., Bittner, M., Brokopf, R., Brovkin, V., Claussen, M., Crueger, T., Esch, M., et al., 2019. Developments in the MPI-M Earth System Model version 1.2 (MPI-ESM1. 2) and its response to increasing $\mathrm{CO}_{2}$. J. Adv. Modelling Earth Syst. 11, 998-1038.

Mayet, C., Testut, L., Legresy, B., Lescarmontier, L., Lyard, F., 2013. High-resolution barotropic modeling and the calving of the Mertz Glacier, East Antarctica. J. Geophys. Res.: Oceans 118, 5267-5279. http://dx.doi.org/10.1002/jgrc.20339.

Menviel, L., Timmermann, A., Timm, O.E., Mouchet, A., 2010. Climate and biogeochemical response to a rapid melting of the West Antarctic Ice Sheet during interglacials and implications for future climate. Paleoceanography 25.

Merino, N., Jourdain, N.C., Le Sommer, J., Goosse, H., Mathiot, P., Durand, G., 2018. Impact of increasing antarctic glacial freshwater release on regional sea-ice cover in the Southern Ocean. Ocean Model. 121, 76-89.

Merino, N., Sommer, J.L., Durand, G., Jourdain, N.C., Madec, G., Mathiot, P., Tournadre, J., 2016. Antarctic icebergs melt over the Southern Ocean: Climatology and impact on sea ice. Ocean Model. 104, 99-110. http://dx.doi.org/10.1016/j.ocemod. 2016.05.001.

Mueller, R., Padman, L., Dinniman, M.S., Erofeeva, S., Fricker, H.A., King, M., 2012. Impact of tide-topography interactions on basal melting of Larsen C Ice Shelf, Antarctica. J. Geophys. Res.: Oceans 117.

Nihashi, S., Ohshima, K.I., 2015. Circumpolar mapping of antarctic coastal polynyas and landfast sea ice: Relationship and variability. J. Clim. 28, 3650-3670. http: //dx.doi.org/10.1175/jcli-d-14-00369.1.

Ohshima, K.I., Fukamachi, Y., Williams, G.D., Nihashi, S., Roquet, F., Kitade, Y., Tamura, T., Hirano, D., Herraiz-Borreguero, L., Field, I., et al., 2013. Antarctic Bottom Water production by intense sea-ice formation in the Cape Darnley polynya. Nat. Geosci. 6, 235.

Olason, E., 2016. A dynamical model of Kara Sea land-fast ice. J. Geophys. Res.: Oceans 121, 3141-3158. http://dx.doi.org/10.1002/2016jc011638.

Padman, L., Howard, S.L., Orsi, A.H., Muench, R.D., 2009. Tides of the northwestern Ross Sea and their impact on dense outflows of Antarctic Bottom Water. Deep-Sea Res. II 56, 818-834. http://dx.doi.org/10.1016/j.dsr2.2008.10.026.

Padman, L., Siegfried, M.R., Fricker, H.A., 2018. Ocean tide influences on the antarctic and greenland ice sheets. Rev. Geophys. 56, 142-184. http://dx.doi.org/10.1002/ 2016 rg000546.

Pardo, P.C., Pérez, F.F., Khatiwala, S., Ríos, A.F., 2014. Anthropogenic $\mathrm{CO}_{2}$ estimates in the Southern Ocean: Storage partitioning in the different water masses. Prog. Oceanogr. 120, 230-242. 
Pauling, A.G., Bitz, C.M., Smith, I.J., Langhorne, P.J., 2016. The response of the Southern Ocean and Antarctic sea ice to freshwater from ice shelves in an Earth system model. J. Clim. 29, 1655-1672.

Purkey, S.G., Johnson, G.C., 2013. Antarctic Bottom Water warming and freshening: Contributions to sea level rise, ocean freshwater budgets, and global heat gain. J. Clim. 26, 6105-6122.

Rignot, E., 2002. Mass balance of East Antarctic glaciers and ice shelves from satellite data. Ann. Glaciol. 34, 217-227.

Rignot, E., Jacobs, S., Mouginot, J., Scheuchl, B., 2013. Ice-shelf melting around Antarctica. Science 341, 266-270. http://dx.doi.org/10.1126/science.1235798.

Rintoul, S.R., 1998. On the origin and influence of Adélie Land Bottom Water. In: Ocean, Ice, and Atmosphere: Interactions at the Antarctic Continental Margin, Vol. 75. pp. 151-171.

Rintoul, S.R., 2007. Rapid freshening of Antarctic Bottom Water formed in the Indian and Pacific oceans. Geophys. Res. Lett. 34

Rousset, C., Vancoppenolle, M., Madec, G., Fichefet, T., Flavoni, S., Barthélemy, A., Benshila, R., Chanut, J., Levy, C., Masson, S., Vivier, F., 2015. The Louvain-LaNeuve sea ice model LIM3.6: global and regional capabilities. Geosci. Model Dev. 8, 2991-3005. http://dx.doi.org/10.5194/gmd-8-2991-2015.

Sallée, J.B., Shuckburgh, E., Bruneau, N., Meijers, A.J., Bracegirdle, T.J., Wang, Z., Roy, T., 2013. Assessment of Southern Ocean water mass circulation and characteristics in CMIP5 models: Historical bias and forcing response. J. Geophys. Res.: Oceans 118, 1830-1844.

Schloesser, F., Friedrich, T., Timmermann, A., DeConto, R.M., Pollard, D., 2019. Antarctic iceberg impacts on future Southern Hemisphere climate. Nature Clim. Change 9, 672-677.

Semmler, T., Danilov, S., Gierz, P., Goessling, H.F., Hegewald, J., Hinrichs, C., Koldunov, N., Khosravi, N., Mu, L., Rackow, T., et al., 2019. Simulations for CMIP6 with the AWI climate model AWI-CM-1-1. J. Adv. Modelling Earth Syst. e2019MS002009.

Silvano, A., Rintoul, S.R., Peña-Molino, B., Hobbs, W.R., van Wijk, E., Aoki, S., Tamura, T., Williams, G.D., 2018. Freshening by glacial meltwater enhances melting of ice shelves and reduces formation of Antarctic Bottom Water. Sci. Adv. 4, eaap9467.

Snow, K., Rintoul, S.R., Sloyan, B.M., Hogg, A.M., 2018. Change in dense shelf water and Adéie land bottom water precipitated by Iceberg calving. Geophys. Res. Lett. 45, 2380-2387. http://dx.doi.org/10.1002/2017gl076195.

Snow, K., Sloyan, B., Rintoul, S., Hogg, A.M., Downes, S., 2016. Controls on circulation, cross-shelf exchange, and dense water formation in an Antarctic polynya. Geophys. Res. Lett. 43, 7089-7096.

Spreen, G., Kaleschke, L., Heygster, G., 2008. Sea ice remote sensing using AMSR-E 89-GHz channels. J. Geophys. Res.: Oceans 113.

Stewart, A.L., Klocker, A., Menemenlis, D., 2018. Circum-Antarctic shoreward heat transport derived from an Eddy-and tide-resolving simulation. Geophys. Res. Lett. $45,834-845$.
Stocker, T.F., Wright, D.G., Broecker, W.S., 1992. The influence of high-latitude surface forcing on the global thermohaline circulation. Paleoceanography 7, 529-541.

Storkey, D., Blaker, A.T., Mathiot, P., Megann, A., Aksenov, Y., Blockley, E.W., Calvert, D., Graham, T., Hewitt, H.T., Hyder, P., et al., 2018. UK Global Ocean GO6 and GO7: A traceable hierarchy of model resolutions. Geosci. Model Dev. 11, 3187-3213.

Tamura, T., Ohshima, K.I., Fraser, A.D., Williams, G.D., 2016. Sea ice production variability in Antarctic coastal polynyas. J. Geophys. Res.: Oceans 121, 2967-2979.

Tamura, T., Ohshima, K.I., Nihashi, S., 2008. Mapping of sea ice production for Antarctic coastal polynyas. Geophys. Res. Lett. 35, http://dx.doi.org/10.1029/ 2007gl032903, n/a-n/a.

Tamura, T., Williams, G.D., Fraser, A.D., Ohshima, K.I., 2012. Potential regime shift in decreased sea ice production after the Mertz Glacier calving. Nature Commun. 3, http://dx.doi.org/10.1038/ncomms1820.

Vancoppenolle, M., Fichefet, T., Goosse, H., Bouillon, S., Madec, G., Maqueda, M.A.M., 2009. Simulating the mass balance and salinity of Arctic and Antarctic sea ice. 1. Model description and validation. Ocean Model. 27, 33-53. http://dx.doi.org/10. 1016/j.ocemod.2008.10.005.

Wang, Q., Danilov, S., Hellmer, H., Sidorenko, D., Schröter, J., Jung, T., 2013. Enhanced cross-shelf exchange by tides in the western Ross Sea. Geophys. Res. Lett. 40, 5735-5739. http://dx.doi.org/10.1002/2013g1058207.

Wang, Q., Danilov, S., Sidorenko, D., Timmermann, R., Wekerle, C., Wang, X., Jung, T., Schröter, J., 2014. The Finite Element Sea Ice-Ocean Model (FESOM) v. 1.4: formulation of an ocean general circulation model. Geosci. Model Dev. 7, 663-693.

Weatherall, P., Marks, K.M., Jakobsson, M., Schmitt, T., Tani, S., Arndt, J.E., Rovere, M., Chayes, D., Ferrini, V., Wigley, R., 2015. A new digital bathymetric model of the world's oceans. Earth Space Sci. 2, 331-345. http://dx.doi.org/10.1002/ 2015 ea000107.

Wendler, G., Stearns, C., Weidner, G., Dargaud, G., Parish, T., 1997. On the extraordinary katabatic winds of Adé Land. J. Geophys. Res.: Atmos. 102, 4463-4474.

Whitworth, III, T., Orsi, A., Kim, S.J., Nowlin, Jr., W., Locarnini, R., 1998. Water masses and mixing near the Antarctic Slope Front. In: Ocean, Ice, and Atmosphere: Interactions at the Antarctic Continental Margin, Vol. 75. pp. 1-27.

Williams, G.D., Bindoff, N.L., Marsland, S.J., Rintoul, S.R., 2008. Formation and export of dense shelf water from the Adélie Depression, East Antarctica. J. Geophys. Res. 113, http://dx.doi.org/10.1029/2007jc004346.

Zweng, M., Reagan, J., Antonov, J., Mishonov, A., Boyer, T., Garcia, H., Baranova, O., Johnson, D., Seidov, D., Biddle, M., 2013. World Ocean Atlas2013, Vol. 2: Salinity. NOAA Atlas NESDIS 74.

Zweng, M., Reagan, J., Seidov, D., Boyer, T., Locarnini, R., Garcia, H., Mishonov, A., Baranova, O., Weathers, K., Paver, C., Smolyar, I., 2018. World Ocean Atlas 2018, Vol. 2: Salinity. NOAA Atlas NESDIS 82. 